\title{
أسباب البدعة وآثارها من منظور القرآن الكريم
}

\section{دـ عفان عبد الغفور حميد}

أستاذ مشارك بكلية الثريعة والدراسات الإسلامية،

قسم أصول الدين بجامعة الشارقة.

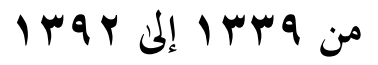


. 


$$
\text { ملخباب البدعة وآثارها من منظور القرآن الكريم الله الرحن الرحيم }
$$

لقد كان المدف من إرسال الرسل هداية البشرية للنجاة بها من الثرك والمعاصي، وصيانة عقل الإنسان من الأوهام والخرافات، وكان من مقاصد الشريعة الإسلامية العبادة القائمة على عقيدة صافية خالية من البدع والفساد، يطابق فيها العمل الإيمان والفعل القول، وبالطبع فإن كل مسلم حريص على أن يكون عمله موافقاً للشرع غير مخالف له، ولا يتم ذلك إلا بتمام الاتباع لما جاء به الرسول وترك المخالفة من زيادة أو نقصان، ولكن من طبيعة الإنسان الخطأ، والوقوع في المعاصي - خلال البدع - في مجالات الدين كلها اعتقاداً وقولاً وعملاً. وهكذا لهن أصاب المسلمين ما أصاب غيرهم من داء الأمم في الزيغ عن المنبع الصافي، فضلاً عن التقليد المذموم واتباع سنن من قبلهم. وظهور البدع من ضمن ما ابتلي به المسلمون قديماً وحديثاً، وكان له الأثر

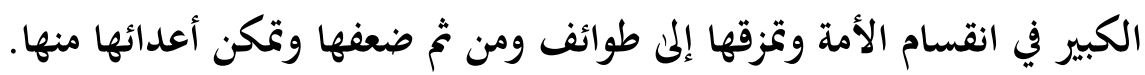
ولقد اشتهر عند الصحابة والتابعين وأهل العلم المقابلة بين السنة والبدعة وقالوا: ما أحدث قوم بدعة إلا أضاعوا مثلها من السنة، وعلى هذا لا بد للمسلم أن يملك المعيار الصحيح الذي يمكنه بوساطته التعامل مع المسائل التي تواجهه في

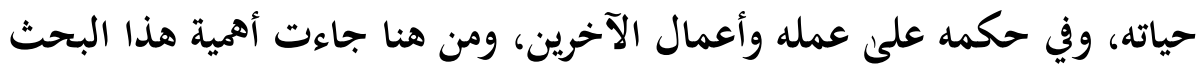
لمعرفة أمرين اثنين هما: بيان أسباب وقوع البعض في البدع، وبيان آثار هذه البدع على الفرد والجمتمع المسلم. والبحث يقع في تمهيد ومبحثين وخاتمة: التمهيد في مفهوم البدعة المبحث الأول: أسباب البدعة من منظور القرآن الكريم 
المبحث الثاني: أضرار البدعة وآثارها من منظور القرآن الكريم

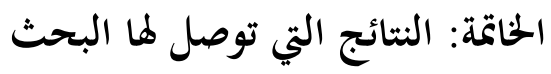

والله الموفق 


\section{التمهيد: مفهوم البد عة}

\section{المعنـى اللغويى والاصطلاهي البد عة:}

البدعة لغة: تطلق البدعة في اللغة على معنيين:

الأول: الاختراع على غير مثال سابق، وهو المناسب لموضوع بحثنا. الثاني: التعب والكلال، يقال: بدعت الإبل إذا بركت في الطريق من هزال أو داء

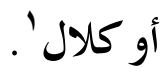

وجاء على المعنى الأول في كتب اللغة الأخرى، منها كتاب العين: "البدع: الشيء

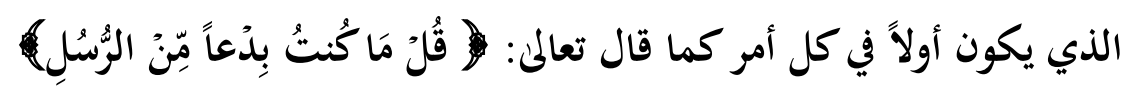
الأحقاف: 9، أي: لست بأول مرسل.

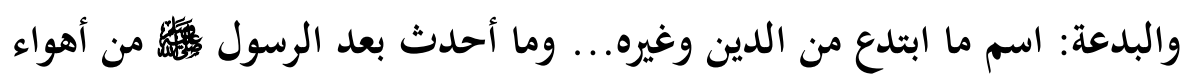

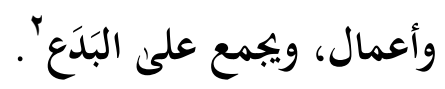

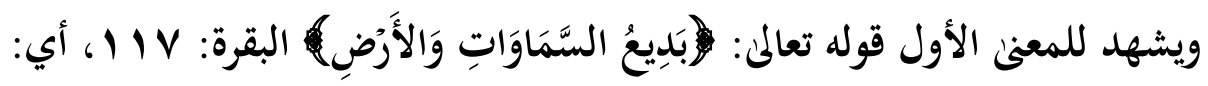
مخترعها من غير مثال سابق '. كما أن الأصل اللغوي الأول يتفق تماماً مع البدعة بالمعنى الثرعي الذي يأتي

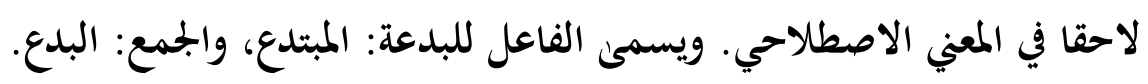
المنه الاصطلاحيه للعلماء تعاريف كثيرة منها: قال ابن منظور: "الحدث، وما ابتدع من الدين بعد

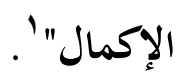

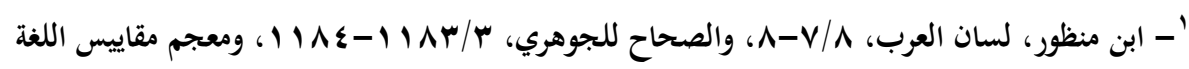
.r. $1 .-r \cdot 9 / 1$

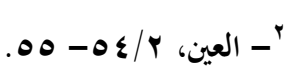

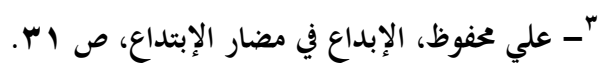


وعرّفها ابن رجب فقال: "المراد بالبدعة: ما أحدث مما لا أصل له في الشريعة يدل عليه، وأما ما كان له أصل من الشرع يدل عليه فليس ببدعة شرعاً، وإن كان بدعة

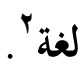
ويعرفها الشاطبي بتعريفين: الأول: "طريقة في الدين مخترعة، تضاهي الشرعية يقصد بالسلوك عليها المبالغة في التعبد لله سبحانه"، والآخر : "طريقة في الدين مخترعة، تضاهي الشرعية، يقصد

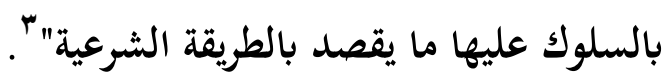

فالتعريف الأول يخص البدعة بالعبادات، على رأي من لا يدخل العادات فيها، وأما التعريف الثاني فهو عام في العبادات والعادات. أما الثافعي فيقول: "البدعة بدعتان: بدعة مذمومة، وبدعة محمودة، فما

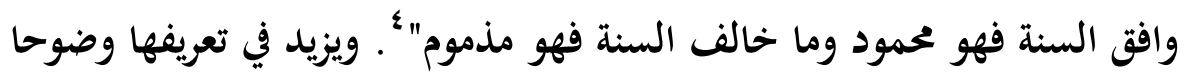
فيقول: المحدثات من الأمور ضربان: أحدهما: ما أحدث يخالف كتاباً أو سنة أو

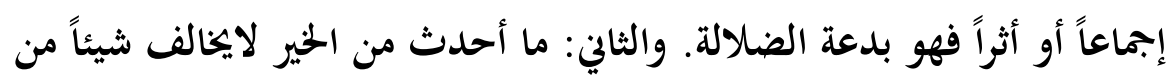
ذلك فهذه بدعة غير مذمومة.

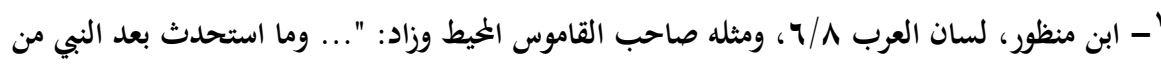

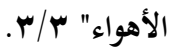

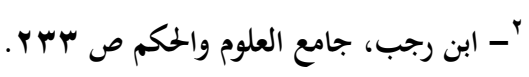

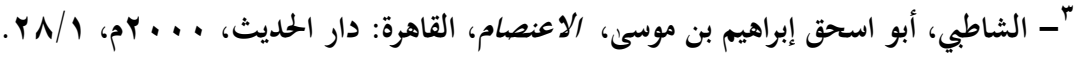

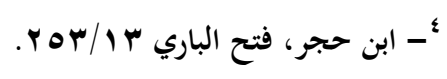

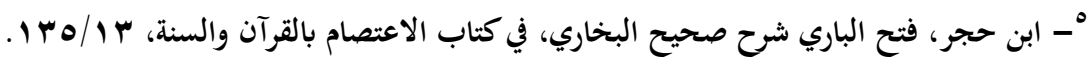


وعلى ذلك بنى شيخ الإسلام عز الدين ابن عبد السلام (ت • 7 7 هـ)، وتلميذه الإمام شهاب الدين القرافي (ت ع \\هـ)، مذهبهما في تقسيم البدعة كما سيأتي في مبحث أقسام البدعة. أما ابن تيمية فيفصّل في التعريف فيقول: "البدعة في الدين: هي ما لم يشرعه الله ورسوله، وهو ما لم يأمر به أمر إيجاب، ولا استحباب... فأما ما أمر به أمر إيجاب، أو استحباب، وعلم الأمر به بالأدلة الشرعية، فهو من الدين الذي شرّعه الله، وإن تنازع أولو الأمر في بعض ذلك، وسواء كان هذا مفعولاً على عهد النبي ' ' وقد عرف الحافظ ابن حجر البدعة الشرعية بقوله: "ما أحدث في الدين وليس له دليل عام ولا خاص يدل عليه" .

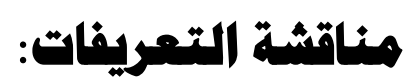

عند مقارنة هذه التعريفات نجد أن تعريف ابن منظور وما شابهه خاص بالبدعة الشرعية أو التعبدية على الخصوص ولم يتطرق إلى بدعة العادات.

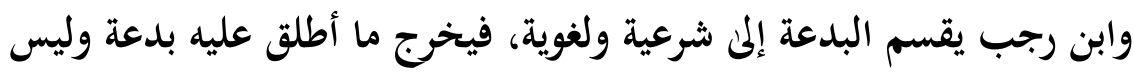

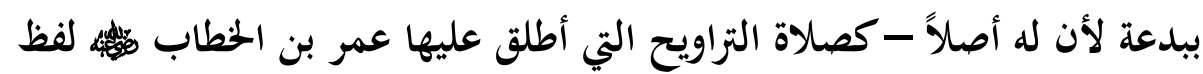

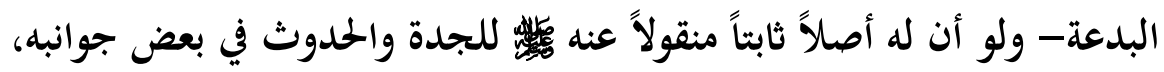
كما يلتقي تعريف ابن رجب مع تعريف الثافعي في تقسيم البدعة إلم بدعة ضلالة وبدعة غير مذمومة. وتعريف الشافعي - كما عند ابن رجب- أشبه بالتقسيم منه بالتعريف، حيث جعلا المحمود هو البدعة اللغوية، والمذموم هو البدعة الشرعية، وزاد الشافعي

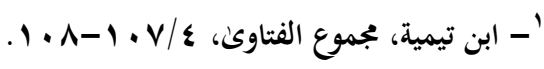

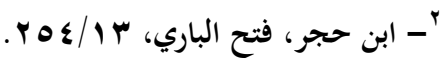


تقسيمه وضوحاً حيث يرى أن البدعة الضالة هي: التي تخالف الكتاب والسنة

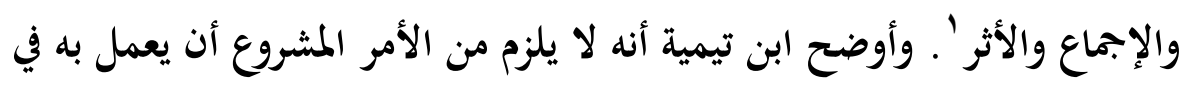

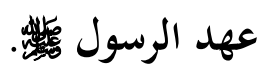

أما تعريف الشاطبي الأول ففيه قيد المبالغة في التعبد وهو قيد خاص بنوع من

المبتدعة وليس على العموم، فقد ينصرف إلمى أهل البدع التعبدية ولا يلاعم بقية

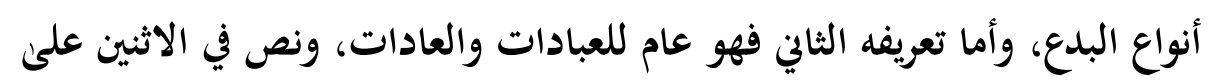
(المضاهاة للشرعية)، وهي على رأي البعض "ليس بلازم للبدعة، ولكنه قد يقصد

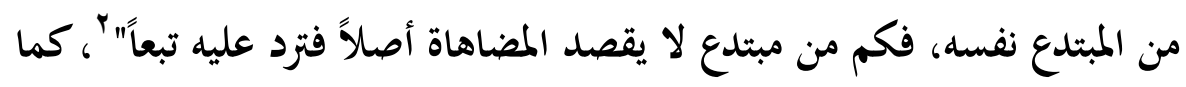
أنه خصّ البدعة الشرعية دون اللغوية.

وهناك تعريفات أخرى كثيرة تقارب ما ذكرناه، ومن خلال هذه التعريفات نجد

أن كلاً منها يركز على جانب من جوانب البدعة أو قسم من أقسامها، إما الشرعية أو التعبدية أو العادية.

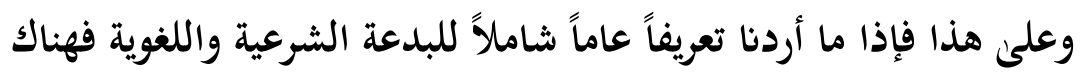

تعريف ابن حجر الذي يقرر أفها: "كل شيء ليس له مثال تقدم"، فيشمل لغة: ما

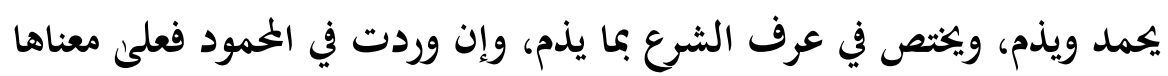

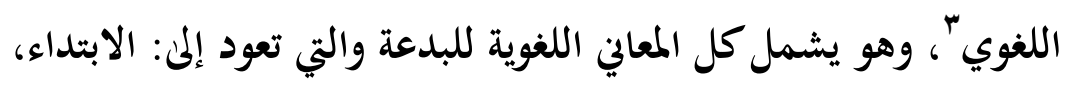
والإنشاء، والاختراع، والجحدة، والحدوث، والأولية.

' - رواه البيهقي في المدخل، مناقب الشافعي، 9/9 \ ؟، وذكره الحافظ ابن حجر في فتح الباري، r r

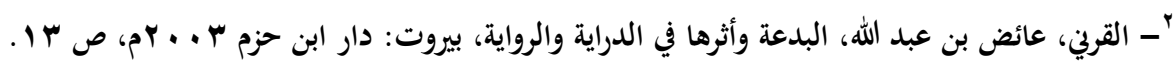

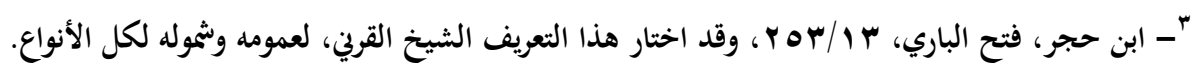


ونظراً لكون موضوعنا أقرب إلى البدعة الشرعية، لمخالفتها السنة فيكون

تعريف الثاطبي هو أقرب هذه الثعريفات لمادتنا، كما أن أكثر كلام العلماء يدور حول تعريفه، ولذلك رأينا أن نتناوله بشئ من التوضيح.

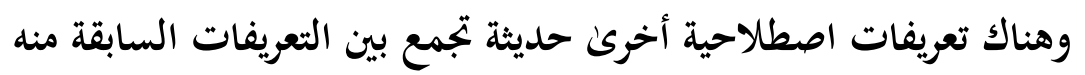
تعريف السعدي حيث يقول: "إحداث فعل أو اعتقاد أو قول لم يرد به إذن من إحن الثارع في كتاب أو سنة أو إجماع أو قياس، ولم يدخل تحت القواعد والمبادئ العامة للإسلام، أو إحداث ما يعارض ذلك ويخالفه" . 
المبحث الأول: أسباب البدعة من منظور القرآن الكريم

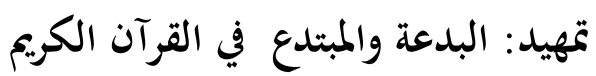

الآيات التي تدل على وجوب التمسك بالكتاب والسنة، وتحذر من الانحراف عنها، ويفهم منها ذم البدعة والمبتدع كثيرة جداً منها:

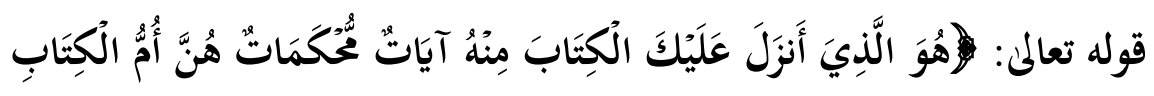

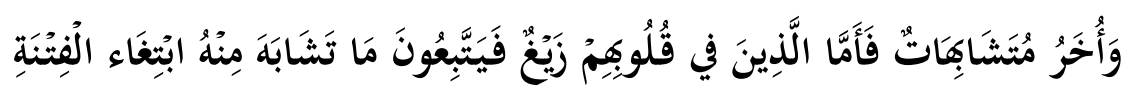

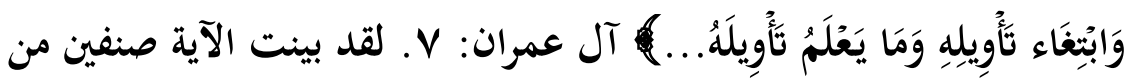

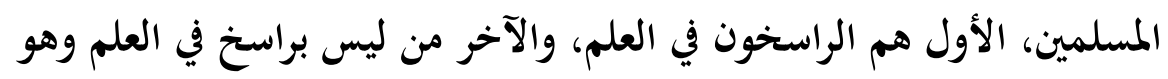

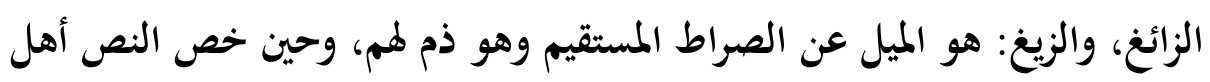

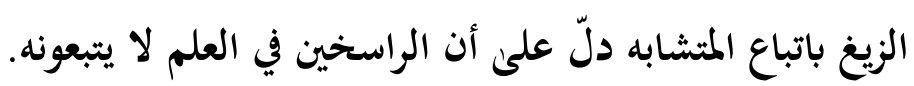

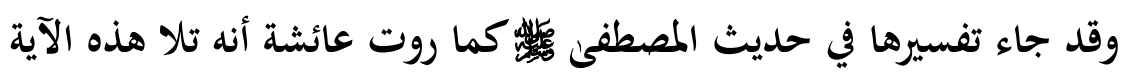

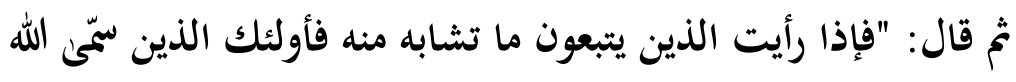

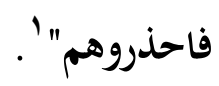

وعن ابن عباس تفسيرها حين ذكر الحوارج وما يصيبهم عند قراءة القرآن

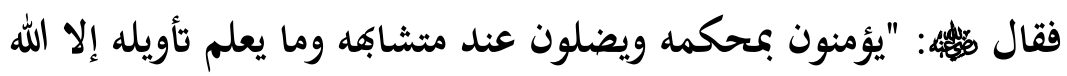
والراسخون في العلم يقولون آمنا به" '.

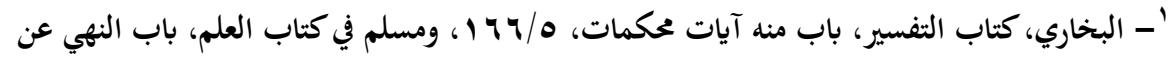

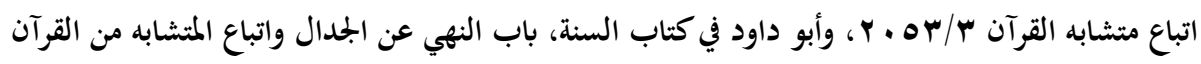

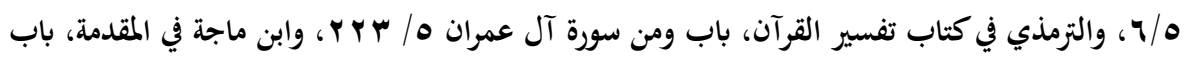

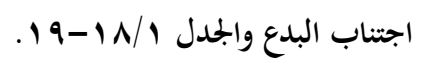

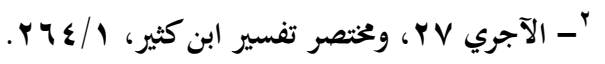




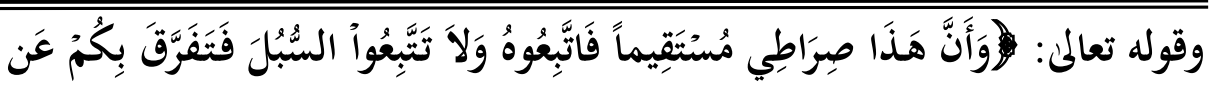

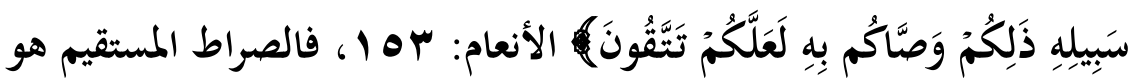
سبيل الله الذي أمر بله، والسبل هي سبل أهل الاختلاف الحائدين عن الصراط

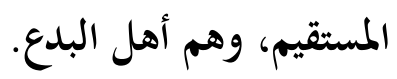

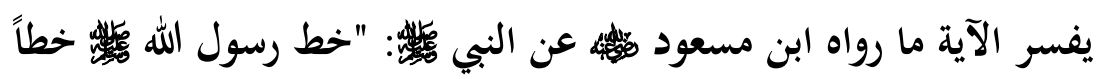
بيده ثم قال: هذا سبيل الله مستقيماً"، قال: ثم خطّ عن يمينه وعن شثماله ثم قال:

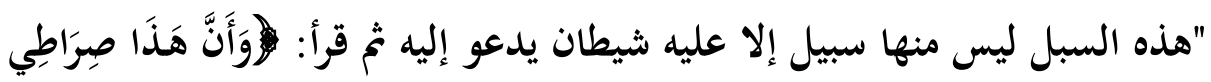

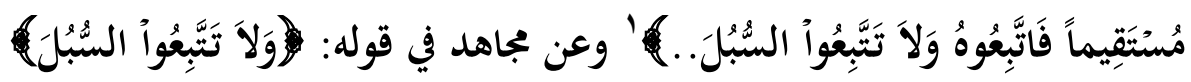

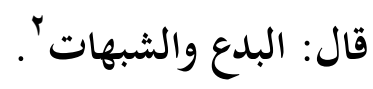
وأرشدت الآية " إلى أن كل ما بينه الرسول كئد من دين الإسلام هو المنهج القويم، والصراط المستقيم، وأرشدت أيضاً إلمى وجوب الاتحاد بين المؤمنين والتلاقي بينهم على ما أمر الله به، والتحذير من الاختلاف والفرقة، واتباع غير سبيل الله، وأن الله بله

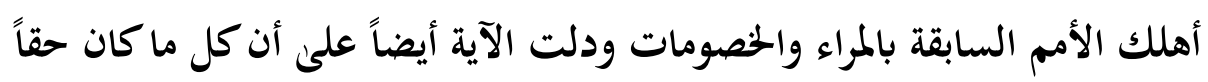

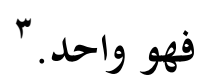

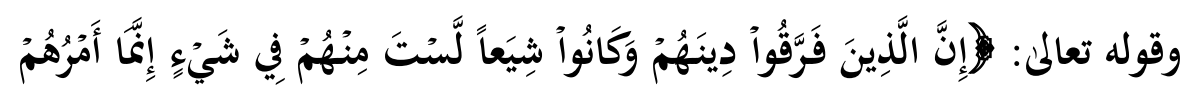

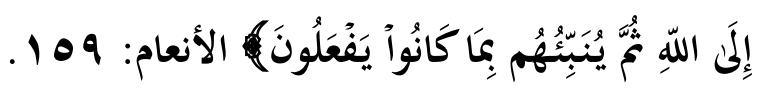

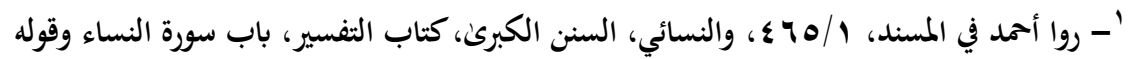

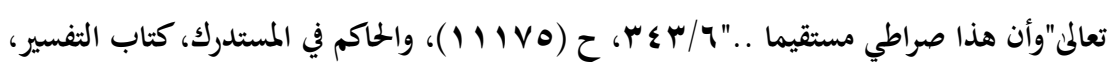
( r ( ) وصححه.

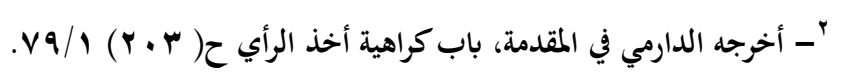

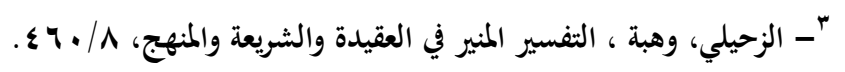


وقد جاء تفسير هذه الآية في حديث عن عائشة رضي الله عنها قالت: قال رسول الله ورسوله أعلم، قال: "هم أصحاب الأهواء وأصحاب البدع والضلالة من هذه الصان

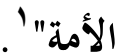

والأدلة على وقوع التفرق والعداوة عند وقوع الابتداع كثيرة وأولها ما وقع من الخوارج حين عادوا أهل الإسلام واستحلوا قتلهم مع تركهم لأهل الأوثان، وصدقت عليهم نبوءة رسول الله

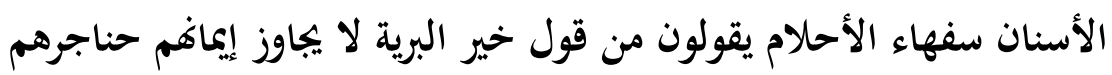

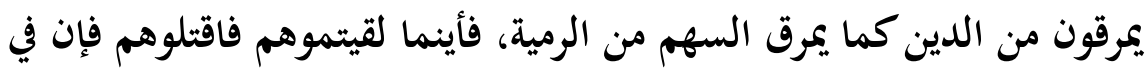

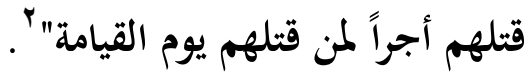

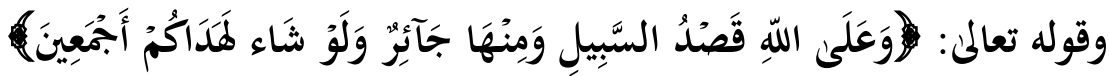
النحل: 9، وعن مجاهد قال :"قصد السبيل" طريق الحقى، وما سواه جائر عن الحق الحق

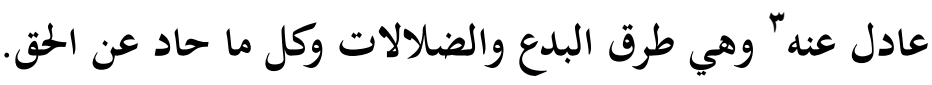

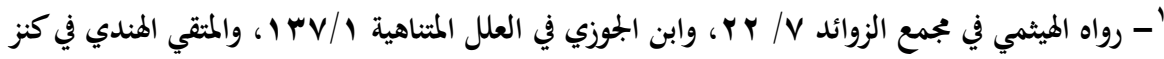

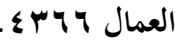

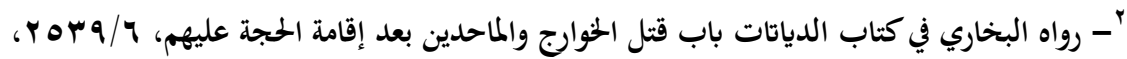

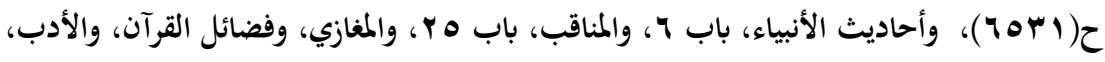

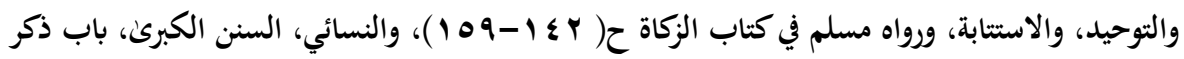

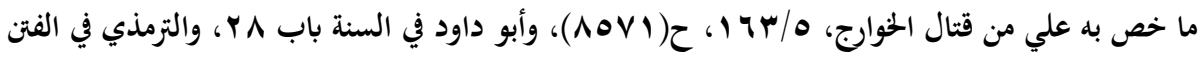
باب ع r، وابن ماجة والدارمي وأحمد ومالك وغيرهم.

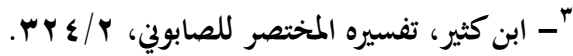


ويمكن الاستدلال على إنكار البدع والنهي عنها بكل الآيات التي توجب

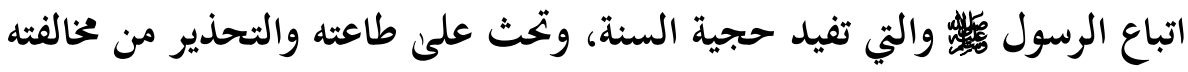
لأن المبتدع مخالف للسنة. وكذلك الآيات التي تدعو إلى الابتعاد عن أهل الأهواء، كما في قوله تعالم:

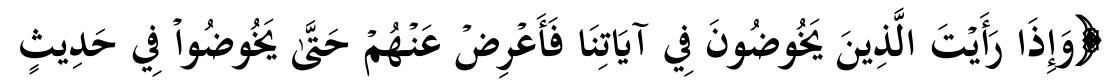

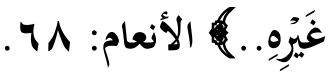

وجاءت أحاديث رسول الله عاس تؤكد على النهي عن البدع وذم المبتدع منها:

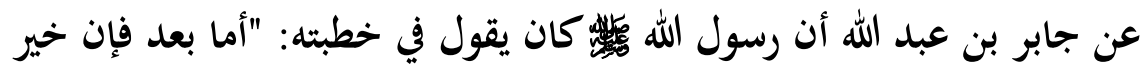

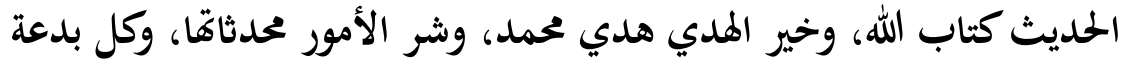

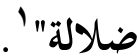

وزاد النسائي: "وكل ضلالة في النار"، وعند ابن ماجة مرفوعاً وموقوفاً على ابن مسعود جاءت الرواية بصيغة التحذير : "إياكم ومحدثات الأمور ...". وعن العرباض بن سارية قال: "صلي بنا رسول الله فوعظنا موعظة بليغة ذرفت منها العيون، ووجلت منها القلوب، فقال قائل: يا رسول الله كأن هذه موعظة مودع، فماذا تعهد إلينا؟ فقال: "أوصيكم بتقوين الله

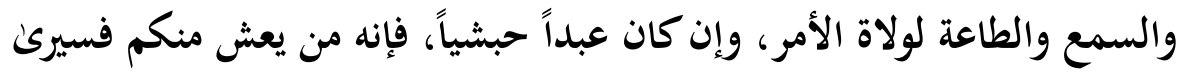

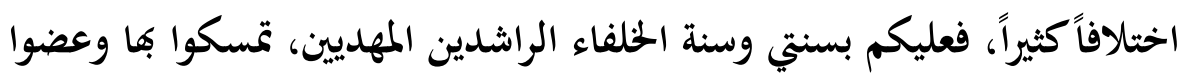

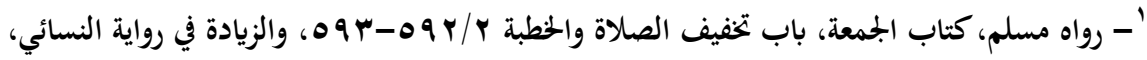

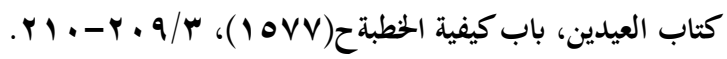


عليها بالنواجذ'، وإياكم ومحدثات الأمور، فإِن كل محدثة بدعة، وكل بدعة ضلالة" با.

وللسلف الصالح والعلماء أقوال كثيرة تؤكد على أن الحروج عن الاتباع لسنة البي باعتبارها استدراك على الشريعة واتمامها بالنقص.

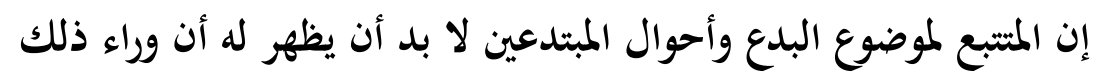

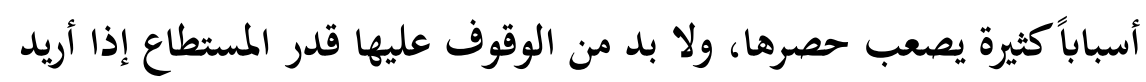

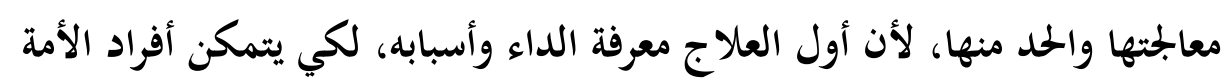
ووجماعاتما من التنبه لها.

وقد تناول العلماء الذين بحثوا في هذا الموضوع أسباباً كثيرة، وقبل أن يشرعوا

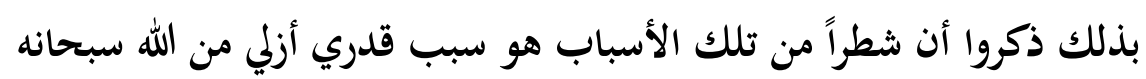

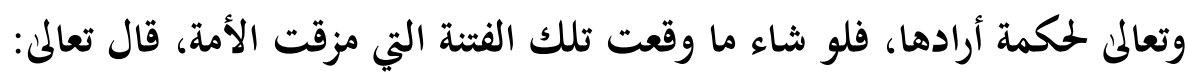

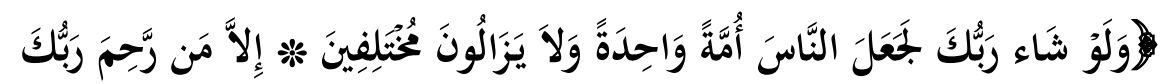

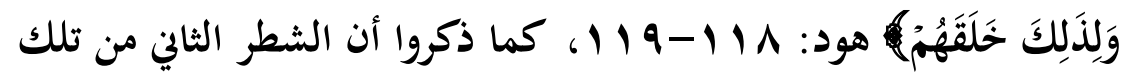

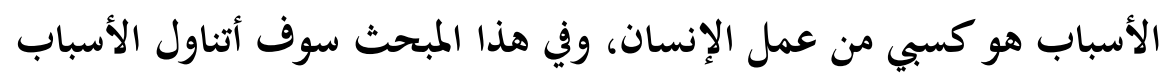

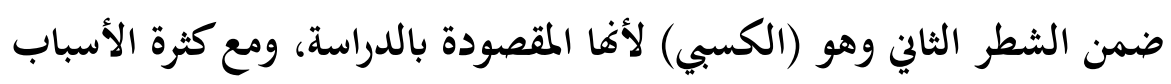

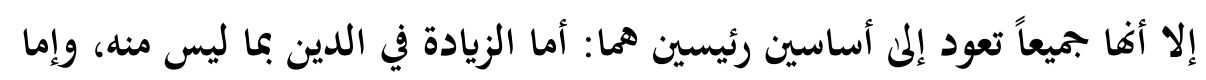

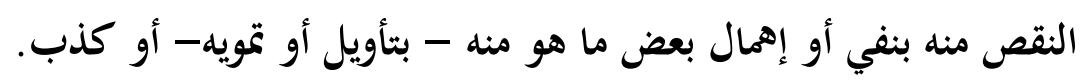

' - النواجذ: الأضراس من الأسنان، وقيل الأنياب، والعض: المسك بجميع الفم، فكأنه يقول: "الزموا السنة واحوصوا عليها كما يحرص العاض على الشيء بنواجذه خوفا من ذهابه وتفلته".

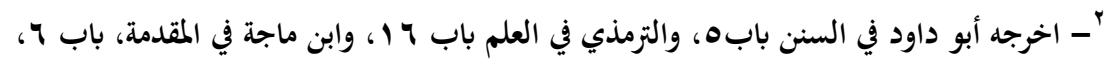

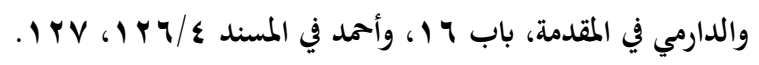




$$
\text { واولاً أهم الأسباب ما يأتي: }
$$

الجهل يؤدي إلى ظهور أنواع كثيرة من الابتداع، والجهل أنواع أهمها:

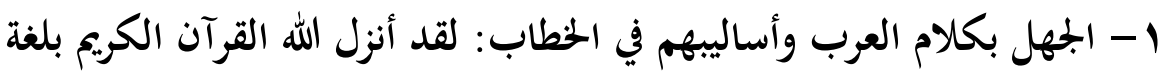

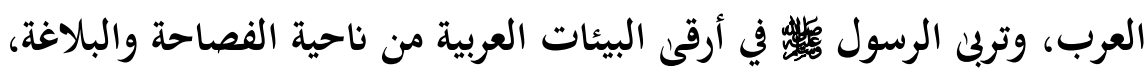

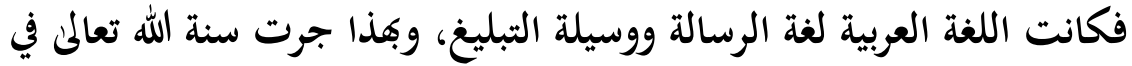

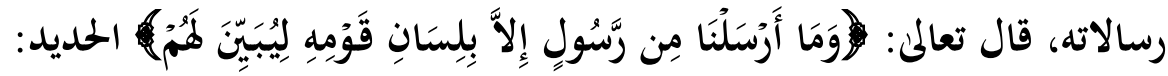

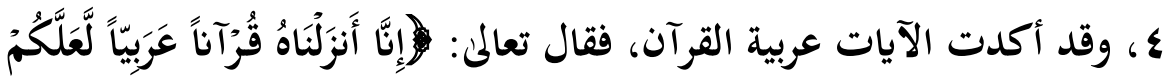

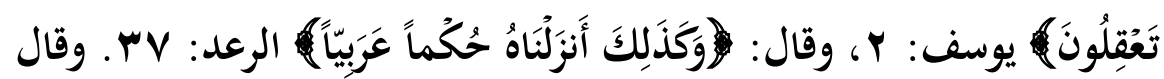

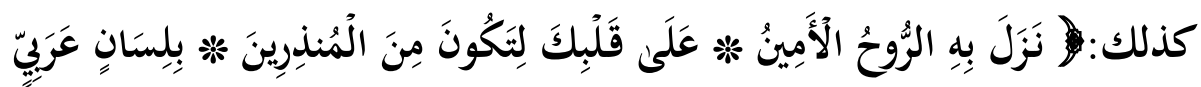

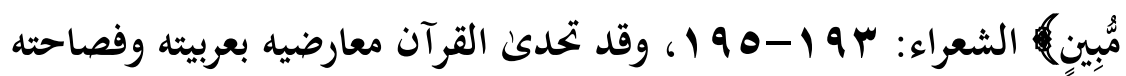
بمراحل متعددة فعجزوا وهم أهل اللغة.

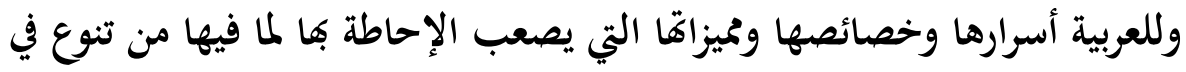

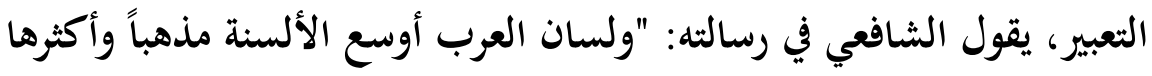

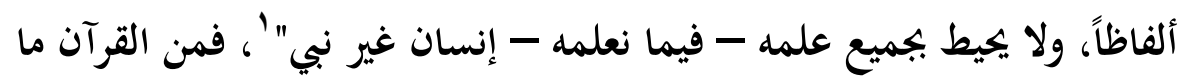
هو عام ويدخله الخصوص، وفيه ما يدل لفظه على باطنه دون ظاهره كما في قوله

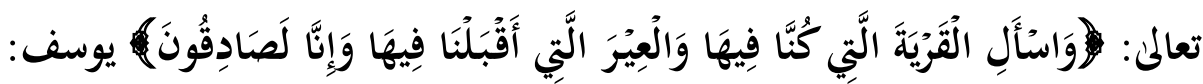

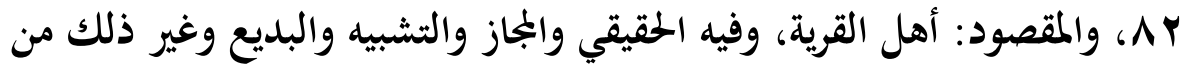
ألوان البلاغة، قال الآلوسي في ذلك: "وسؤال القرية عبارة عن سؤال أهلها، أما 
مجازا في القرية لإطلاقها عليها بعلاقة الحالية والخحلية، أو في النسبة أو يقدر فيه مضاف وهو مجاز أيضا..'

وفي مجال الحديث عن البدعة بسبب الجهل بهذا اللسان، نستطيع أن نقول: إنه كما يجب على الجنهل في الدين أن يبحث ما وسعه البحث عن النصوص التي

يستند إليها ويتفقه فيها، فإِن عليه أن يدرس اللغة العربية ما وسعه الجهد، فيما

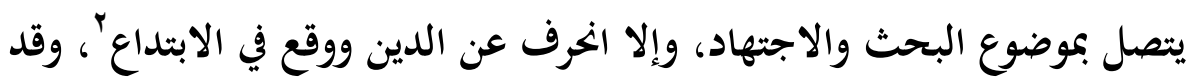

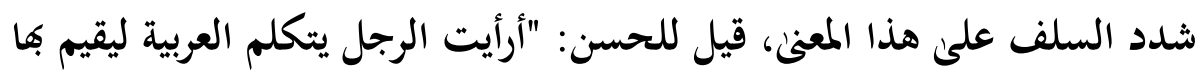

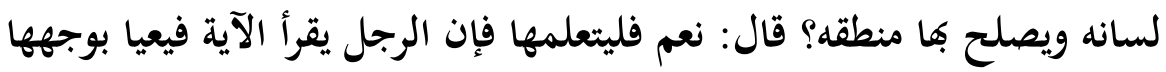

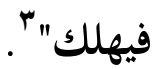
وقد جعل العلماء لزاماً على كل من أراد أن ينظر في الكتاب والسنة أن يتعلم

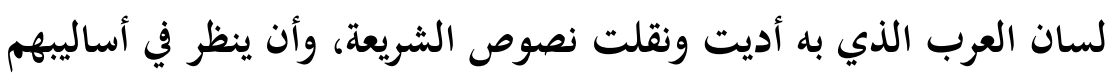

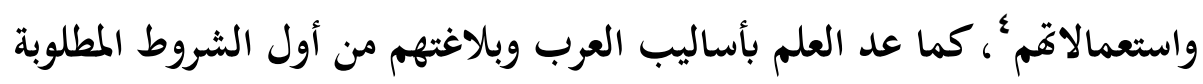

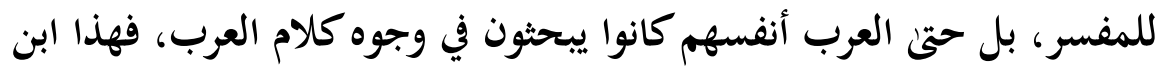

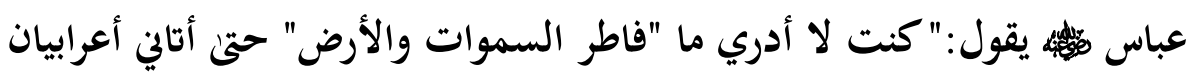
يختصمان في بئر، فقال أحدهما: أنا فطرتما أي أبتدأقهاء.

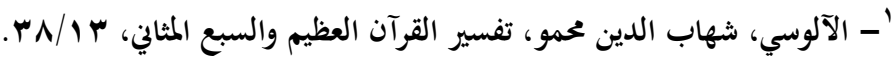

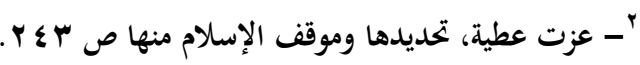

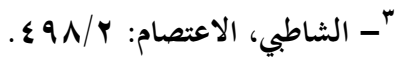

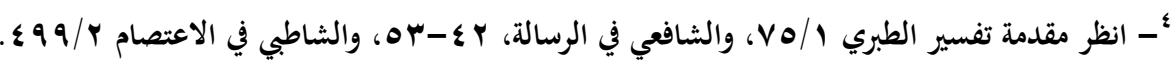

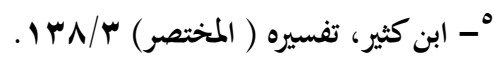


عندما ينظر إلى كلام المبتدعة نجد فيه الخروج على لسان العرب واستعمالاكم، أو الأخذ بالشاذ منها، وقد وقع كثيرون في بدع بسبب الجهل بلسان العرب أو تجاهله، والأمثلة على ذلك كثيرة منها: من ذلك تأويل حديث النبي الرحمن" إلى أن المراد بالإصبعين "قدرتين" ولمذا قال الدارمي: "فهذه ألفاظ رسئ رسول

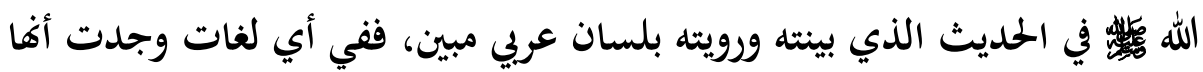
قدرتين من القدر! وهل من شيء ليس تحت قدرة الله التي وسعت كل شيء حتى

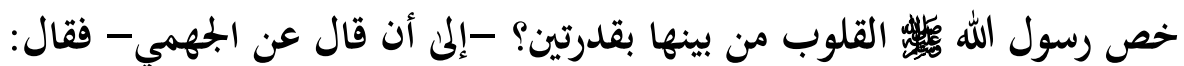

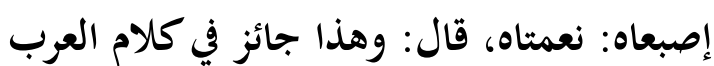

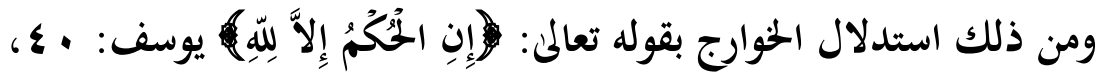
V V على أنه لا يجوز تحكيم أحد في كتاب الله، وما علموا بالأسلوب العربي في الكلام من حيث الإممال والتفصيل والإطلاق والتقييد، ولذلك أعرضوا عن قوله

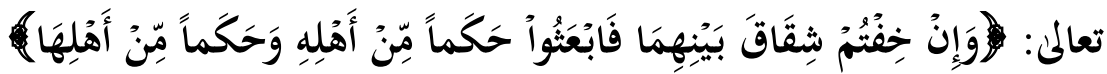

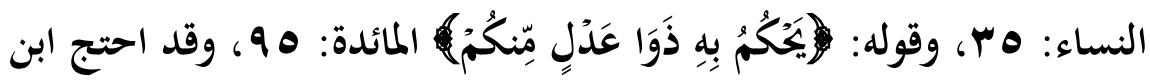

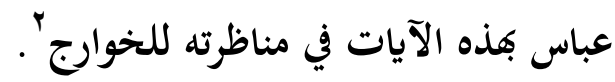
ومن الجهل سوء الفهم للنصوص، مثل استدلال الخارجي على أن أهل الكبائر في

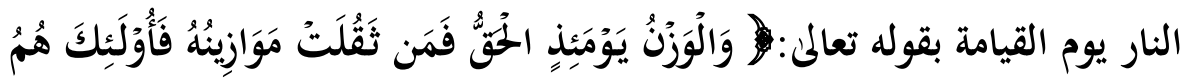

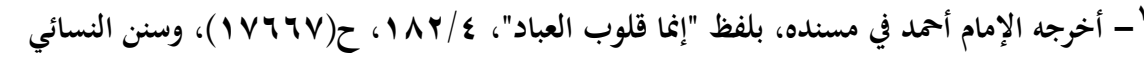

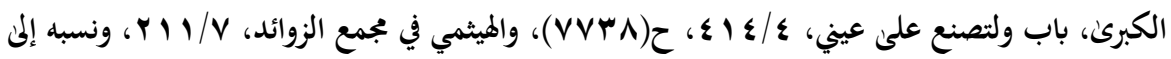
الطبراني في الأوسط، وجاء بمعناه قوله

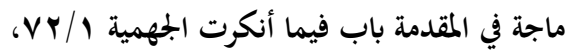

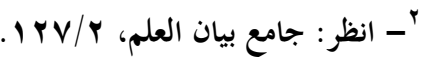




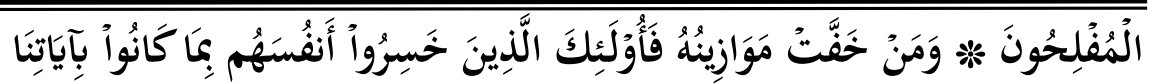

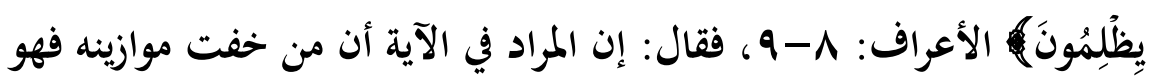
كافر، والمعلوم أن موازين أهل الكبائر قد خفت فيجب أن يكونوا كفرة، ومثله

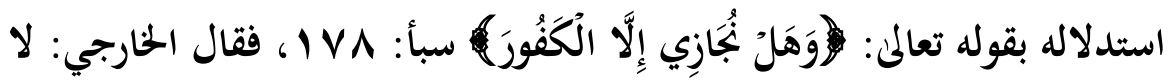

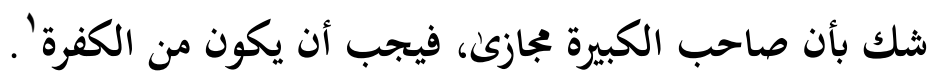

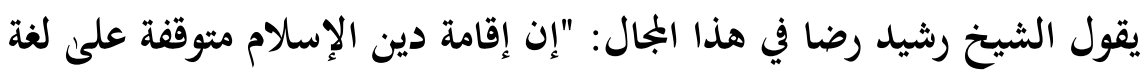
كتابه المنزل، وسنة نبيه المرسل، سواء في ذلك هدايته الروحية، ورابطته

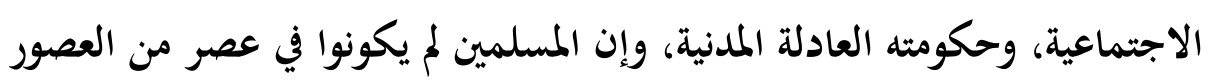

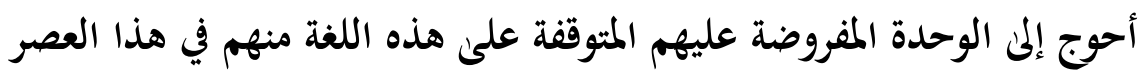

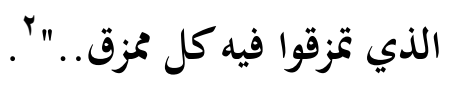

r- الجهل بالسنة: ويشمل الجهل بهذا الجانب شيئين:

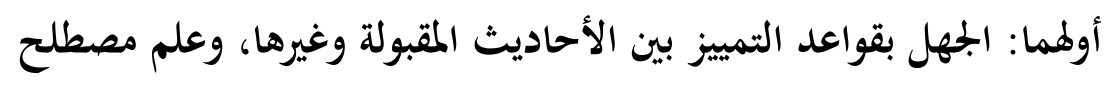

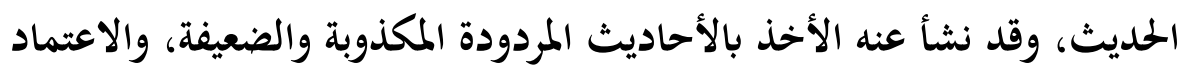

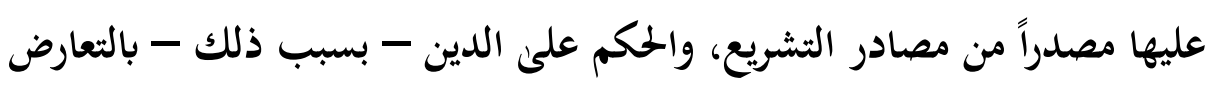

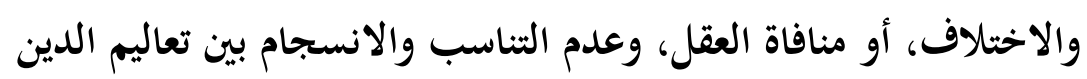

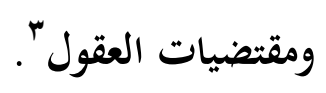

أما بالنسبة للأحاديث الموضوعة فقد اتفق العلماء - عدا فرقة الكرامية

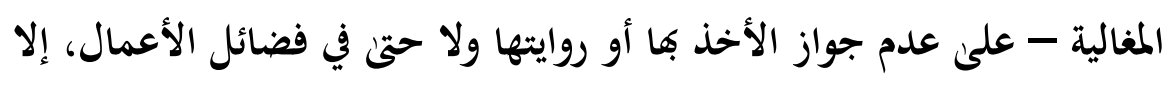

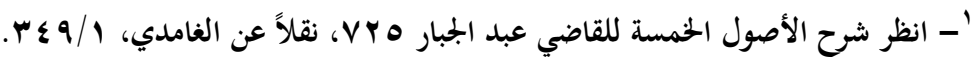

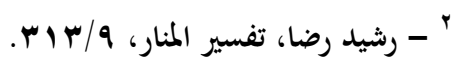

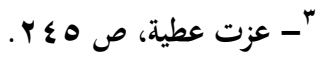


على سبيل التنبيه إليها على أفما مكذوبة على رسول الله

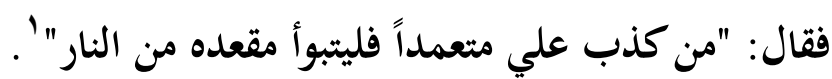

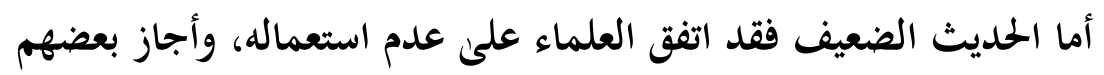

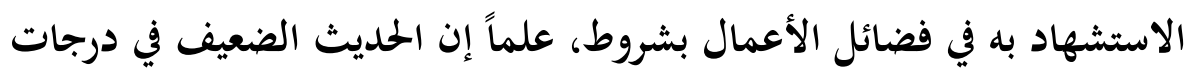

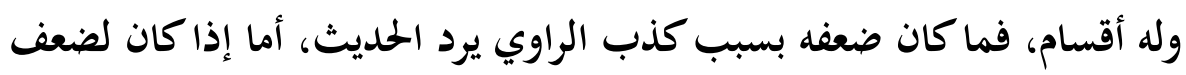

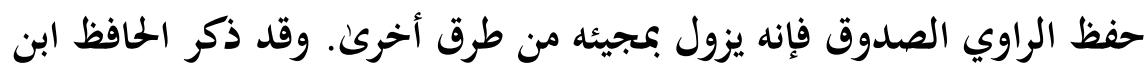
حجر أن للأخذ بالحديث الضعيف في الفضائل - عند من أجاز - ذلك ثلك فلاثة شروط: - ( )

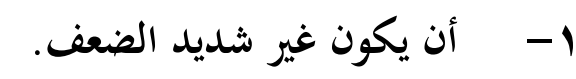

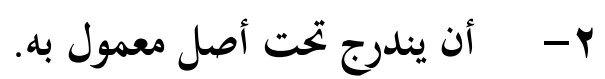

ب- م- أن لا يعتقد عند العمل به ثبوته بل يعتقد الاحتياط.

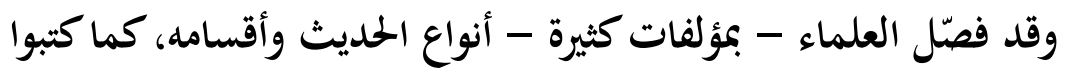
ونبّهوا على الأحاديث الضعيفة والموضوعة وأسباهما، والجحرح والتعديل وعلم المدئ الرجال، كل ذلك من أجل معرفة الدين لأن الأحاديث هي المصدر الثاني للدينا والدين

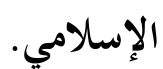

أقول الإمام مسلم في مقدمة صحيحه: "واعلم وفقك الله أن الواجب على كل

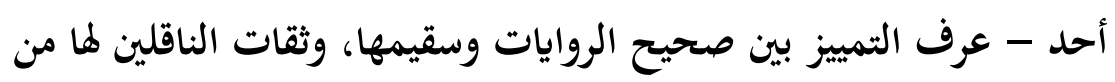

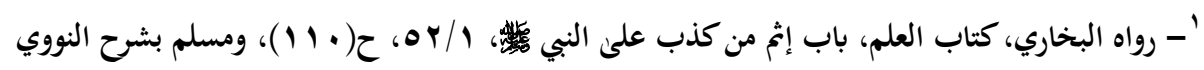

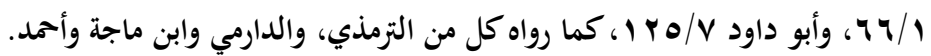


المتهمين- أن لا يروى منها إلا ما عرف صحة مخارجه والستارة في ناقليه، وأن يتقي

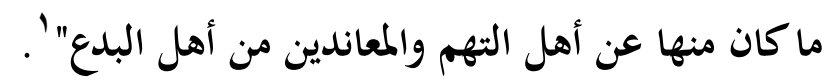
وبالجملة فالعلم بقواعد الحديث يتم على أساسها الحكم على الحديث بالقبول أو الرد. والآخر: الجهل بمكانة السنة من التشريع، وهذا الجهل أدى إلى الخروج عن حد الإتباع الذي وجهت إليه الآيات القرآنية والأحاديث الصحيحة، ومن أظهر المواقف الثائعة فيما يتصل بجذا الموضوع، إنكار ما ثبت بالسنة الصحيحة صريحا واضحاً تحت زعم موافقة العقل، والسير تبعاً لما يقتضيه، مثل إنكار رؤية الله في الآخرة أو نزول المسيح، أو عذاب القبر، ونحو ذلك، مما له أدلة في الصحاح. فمن المبتدعين من أنكر ما عدا القرآن جملة وتفصيلاً وقالوا بالاكتفاء بالقرآن بدعوى دخول الوضع في الحديث، ومنهم من أنكر أحاديث الآحاد، وقد شذّ هؤلاء وهؤلاء للعلاقة الوثيقة بين القرآن وبيانه في السنة النبوية ، كما أن أكثر الفقه من أحاديث الآحاد. وهذا يعني جهالًا أو تجاهلاً بمكانة السنة في التشريع الإسلامي، لأن القرآن يرد عليهم هذه الدعوى لوجود عشرات الآيات التي توجب طاعة الرسول الخروج على توجيهاته.

والناظر في كثير من البدع يجد أن أساسها الأخذ بالرأي مع وجود النص، والتعلل بما يمليه الهوى أو التكلف أو ما إلى ذلك من الأمور، وليس أدل على ذلى ذلك بمان فعله المعتزلة وغيرهم، بكل من عارض أفكارهم وموقفهم من النصوص.

' - الإمام مسلم، صحيح مسلم، المقدمة، باب وجوب الرواية عن الثقات وترك الكذابين، والتحذير من الكذب على رسول الله صئس. 
وعليه فالجهل بعلوم الحديث، وصحة الحديث يترتب عليه إهدار الأحكام التي

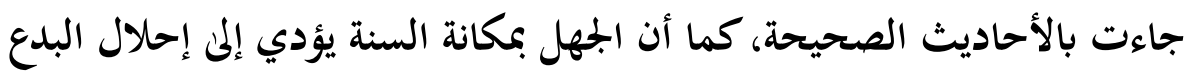
مكان السنن الصحيحة.

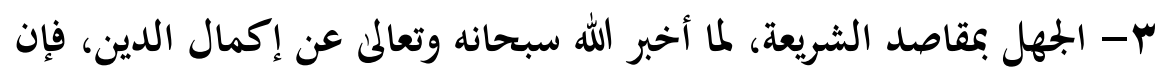

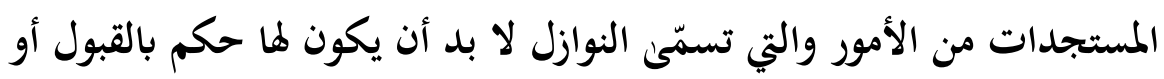
الرد من كليات الدين وقواعده الأساسية التي تنظظم كل الجزئيات الحادثة. وقول الرسول ضلالة" 'يمثل قاعدة شرعية تصوغ لنا مقاصد شرعية أغفلها المبتدعة منها:

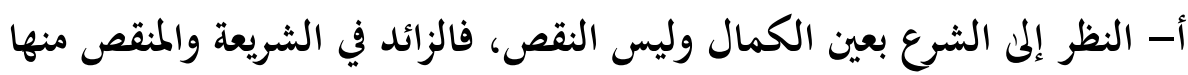
هو المبتدع، وإغفال هذا المقصد الشرعي يجعل المبتدع يستدرك على المئ الشريعة. ب- الإيقان بأن لا تضاد بين آيات القرآن، ولا بين الأخبار النبوية، ولا بين المانين

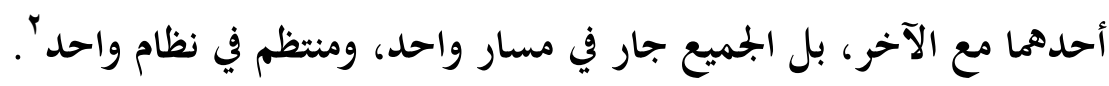

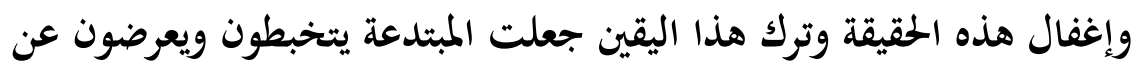

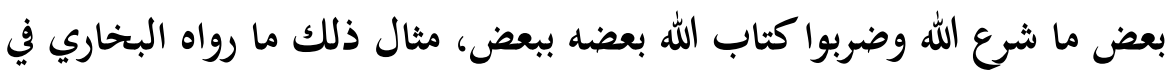

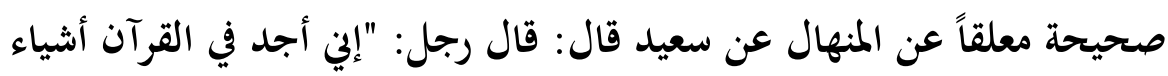

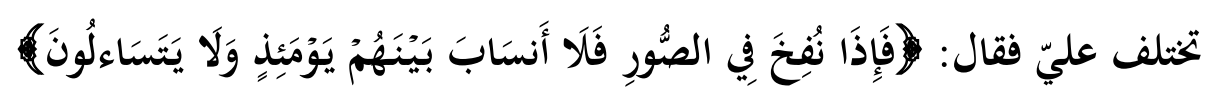

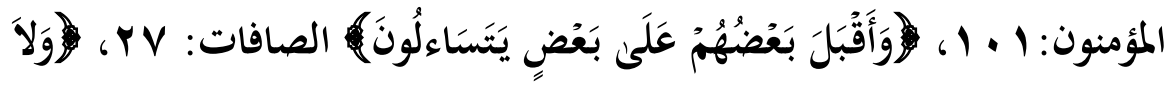

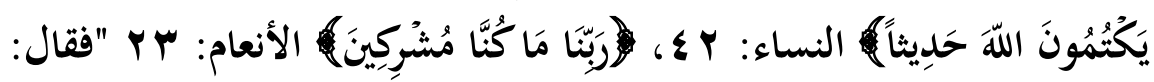

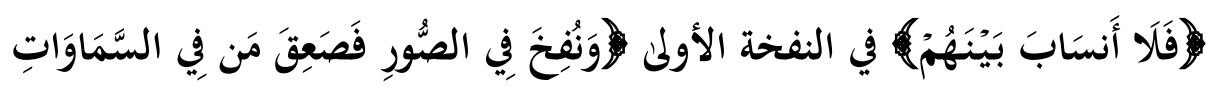

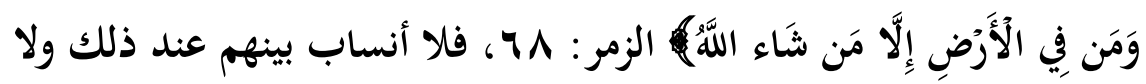


يتساءلون، ثُ في النفخة الأخرى أقبل بعضهم على بعض يتساءلون. أما قوله:

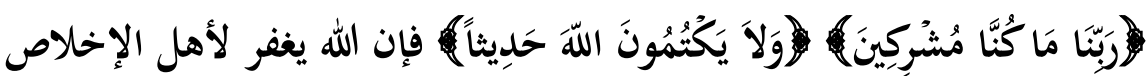
ذنوبم، وقال المشركون: تعالوا نقول: لم نكن مشركين، فختم على أفواههم فتنطق

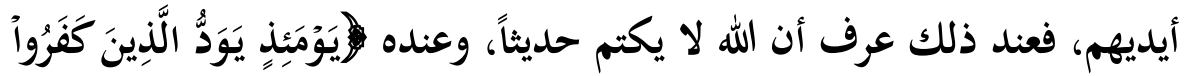

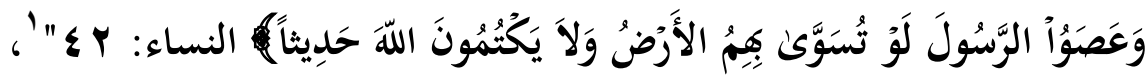

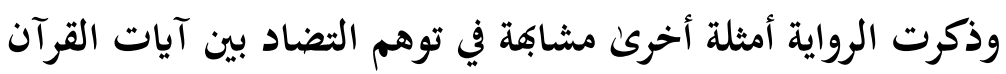

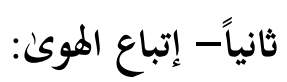
من الأسباب الحططيرة في انتشار البدع بين المسلمين إتباع الموىن، وذلك لأن

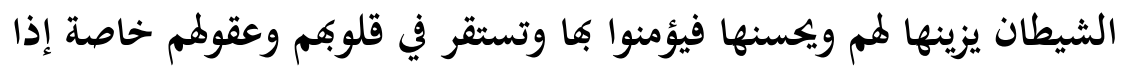
التقت مع الجهل وقلة العلم.

الموي: يطلق على ميل النفس وانخرافها نحو الشيء، ثم استعمل في العمل

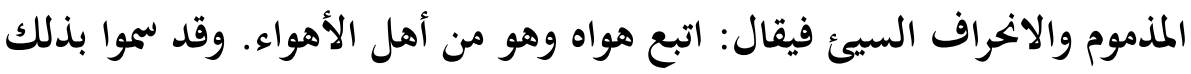

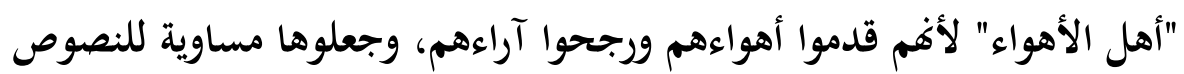

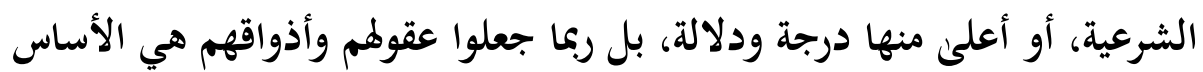

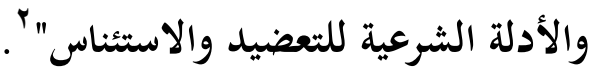

$$
\begin{aligned}
& \text { ' - البخاري، كتاب التفسير، باب تفسير حم السجدة ؟/هץ. }
\end{aligned}
$$

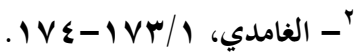


وكان السلف يسموغم أهل الشبهات والأهواء، قال عمر بن الخطاب نهابه: " إياكم وأصحاب الرأي فإغم أعداء السنن، أعيتهم الأحاديث أن يحفظوها فقالوا

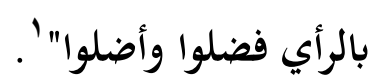
ودأب أهل البدع يضعون أهواءهم أولاً ثم يطلبون لها الأدلة، وإذا وجدوا

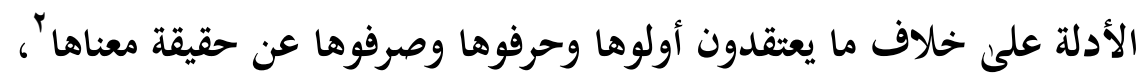
وهذا عكس النهج الصحيح بوضع الدليل أولاً والانقياد له فيحكمون بعدما

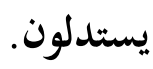

وقد ذمّ الله سبحانه من يتبعون الهوىن ويعرضون عن الحق الذي جاء به الشرع

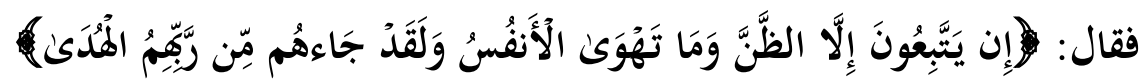

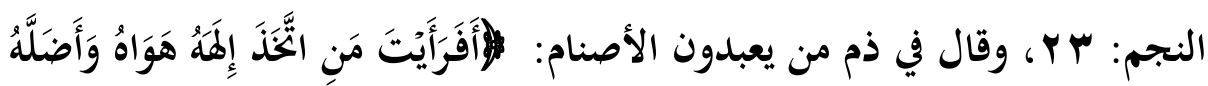

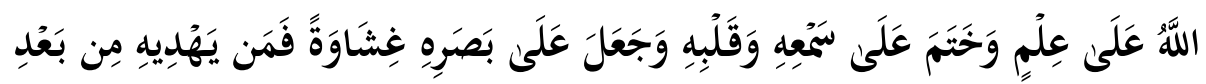

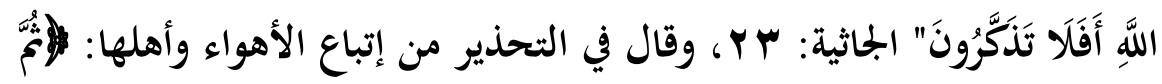

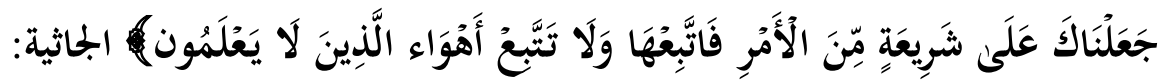

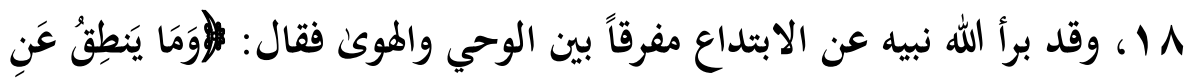

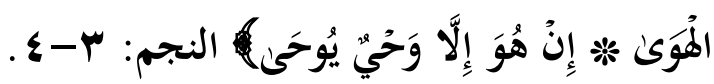

وقد جعل القرآن السبب الأكبر في عدم إتباع الكفار الرسول

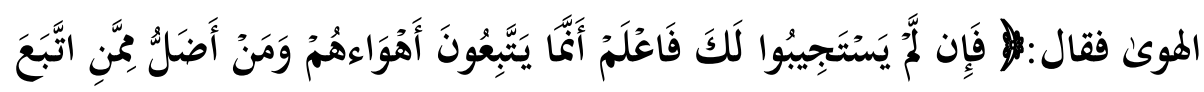

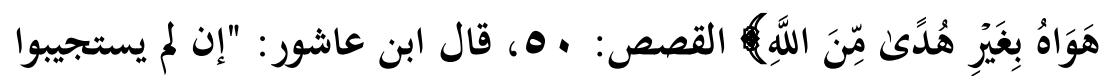
لدعوتك، أي إلم الدين بعد قيام الحجة عليهم بهذا التحدي، فاعلم أن استمرارهم

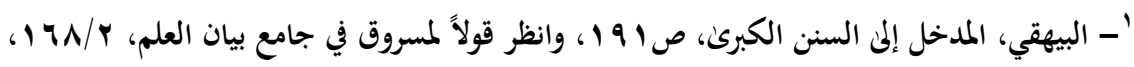

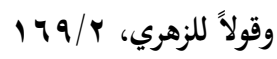
r 
على الكفر بعد ذلك ما هو إلا اتباع للهوكن ولا شبهة لمم في دينهم.... وقوله "بغير هدى من الله" الباء فيه للملابسة وهو في موضع الحال من فاعل "اتبع هواه"

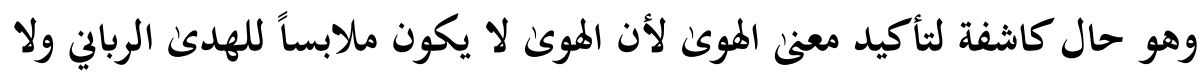

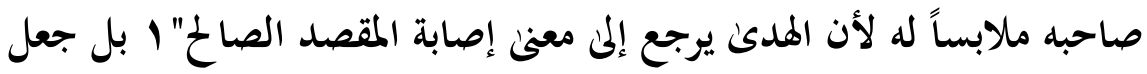

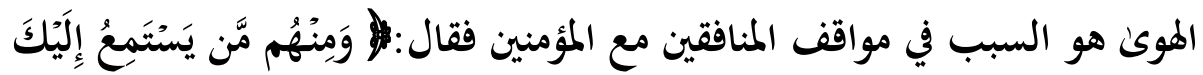

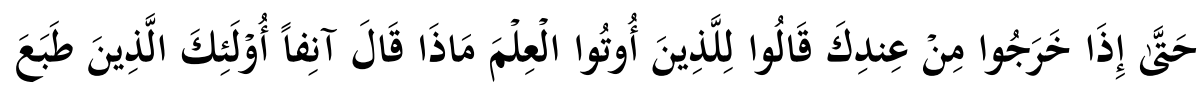

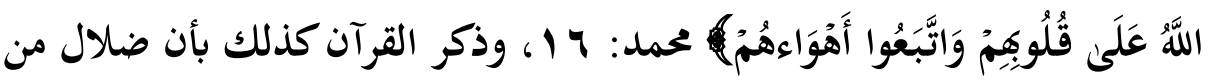

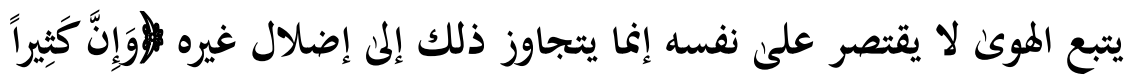

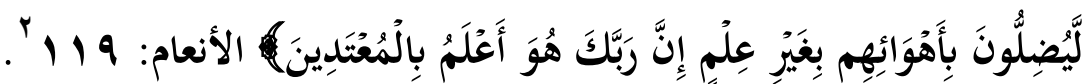
واتباع الهوى لا يقتصر على الجهلة بالعلم فقط بل الأدهى ممن وصل إلى درجة

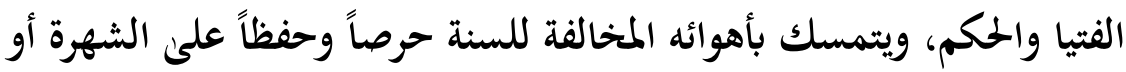
طمعاً في كسب مادي أو تعنتاً في مواجهة الخصوم أو ما إلى ذلك. وقد حكى الله إضلال أهل الكتاب بعد أن أنعم الله عليهم بالكتاب والحكمة، وهو ما حصل لأصحاب البدع من المسلمين، ومما يجعل ذلك في غاية الخطورة أن

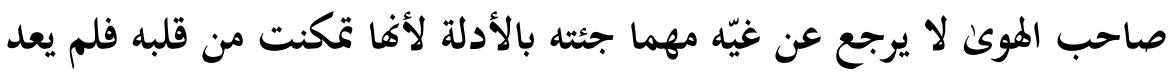

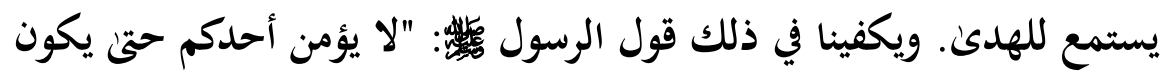

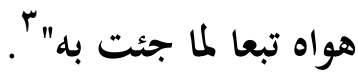

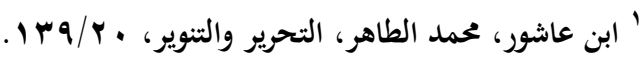

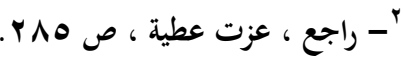

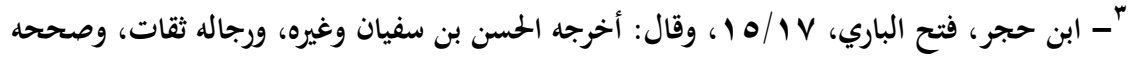

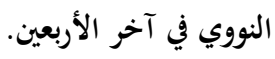


ومن الهوى الاعتماد على العقل الجرد في تفسير النصوص، والإسلام دين الوسطية فلا يريد منا أن نلفي عقولنا ولا نتبع الغلو فيه ونعتبر العقل مصدراً

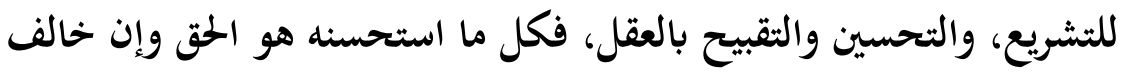
الكتاب والسنة، وبسبب ذلك كثرت البدع وأميتت السنن وحرفت النصوص.

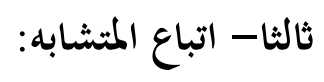

وهو من أسباب الابتداع الخطيرة ممن يبتغون الفتنة والتأويل كما قال تعالمي:

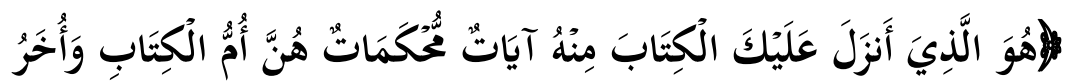

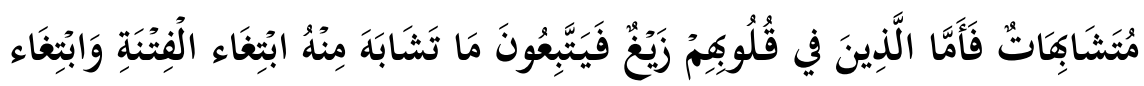

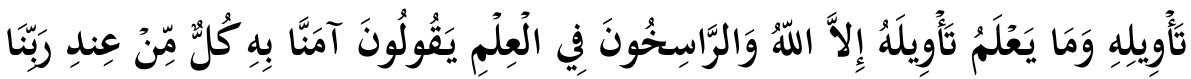

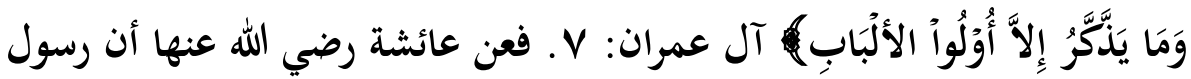
الله

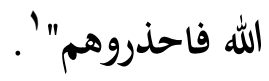

وكان السلف الصالح يتورعون عن إلقاء الثبهات والكلام في المتشابه بل كانوا يشددون في ذلك حتى إذا استفتاهم أحد عن مسألة سألوه هل وقعت أم لا؟ وقد بين العلماء معنى المتشابه بأقوال كثيرة لا يتسع المجال لذكرها وملخصها

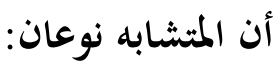
الأول: نوع منعنا من الحوض فيه أو السؤال عنه، والبحث فيه ابتداع مذموم

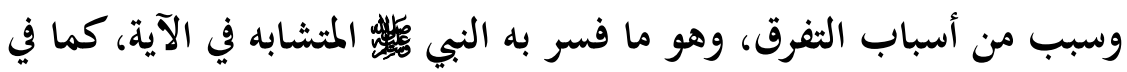
حديث عائشة رضي الله عنها، وهو: ما لا سبيل إلى العلم به، إما لعدم الإعلام به

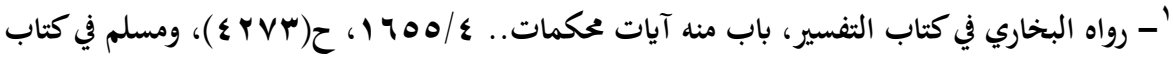

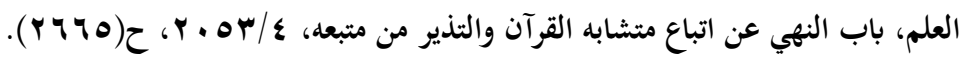


من جهة النقل ولا سبيل إلى علمه بغيره، أو لكونه مما لا يمكن تصوره في النفس، لأنه لم يقع في دائرة الحس.

والثاني: لا يلج بابه إلا من تمكن في العلم، وتحققت له وسائل الاجتهاد، وهو ما لها سماه الراغب المتشابه من جهة اللفظ والمعنى، وسماه الشاطبي المتشابه الإضافي.

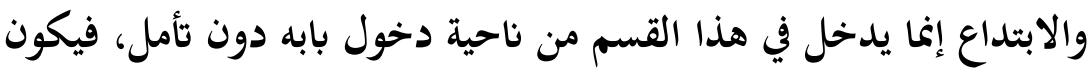

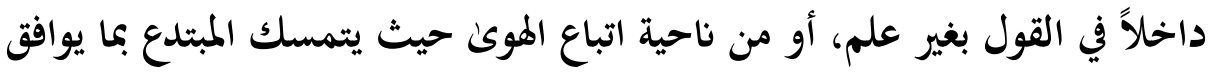
هواه من المعاني الختملة ويرجحه على ما سواه

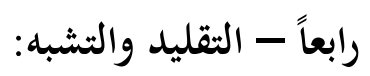

ومن أعظم الأسباب التي أدت إلم ذيوع البدعة وانتشارها بين العوام التقليد

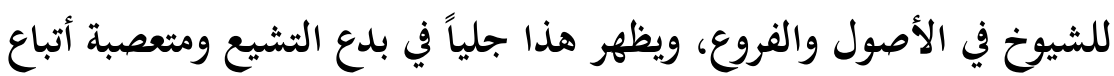
المذاهب الفقهية، كاعتقاد العصمة للأئمة

فقول الإمام الشيعي مقدم عند المبتدعة على قول الله ورسوله، ويأخذونه

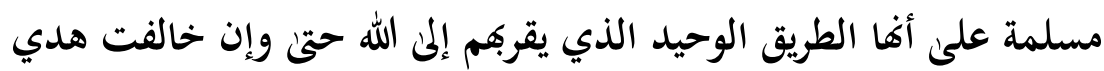
الكتاب والسنة، فيعتقدون أخها من التشريع الذي خصّّ الله به أصفياءه وأولياءه

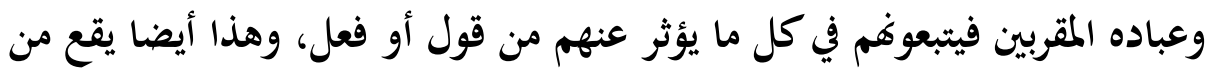
بعض المتعصبين للمذاهب الفقهية حيث يعتقدون العصمة لفقهائهم، ويعتمدون

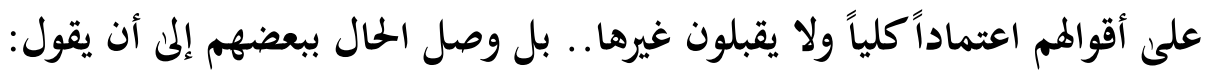

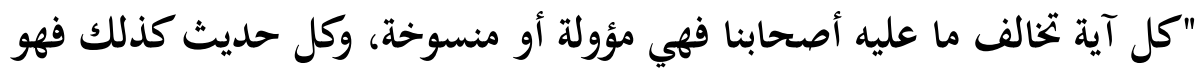

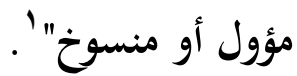

' '- الرسالة في أصول الحنفية لأبي الحسن الكرخي، وتاريخ التشريع للخضري ص بآب، نقلاً عن 
وقد سرى هذا التقليد حتى وجد من يحفظ من متون الفقهاء وهو لا يحفظ بعض قصار السور، فضلا عن أن يحفظ شيئا من السنة، وبذلك انتشرت البدع وعمّت بين الناس وحالت بينهم وبين سماع الحق والهدىن.

والتقليد المذموم في الفقه هو ذلكم التقليد الأعمى الذي يترك به الدليل ولو

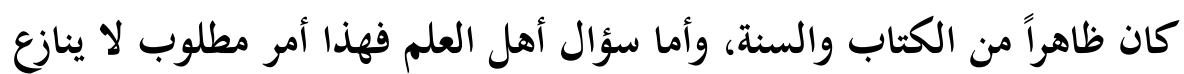

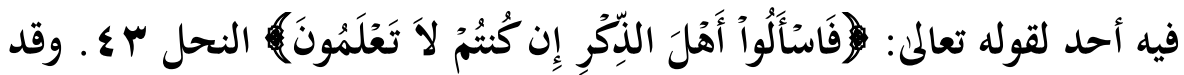

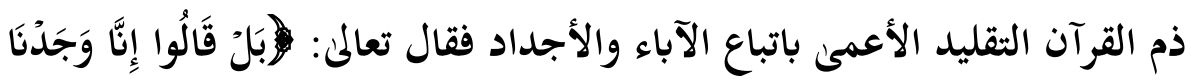

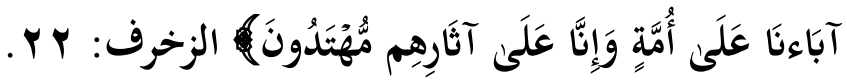
كما جاءت آثار السلف صريحة في ذم التقليد وأهله ، فهذا الشافعي رحمه الله يقول: "أجمع العلماء على أن من استبانت له سنة رسول الله

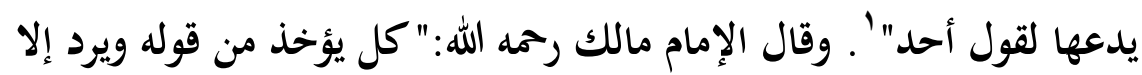

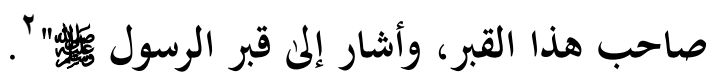
ومثله التعصب للطائفة والتقليد فيها قاد إلى كثير من البدع، إذ أن أكثر فرق المبتدعة تضع لنفسها أصولاً وقواعد بدعية عقلية ـ فمن تقيد بمذه الأصول وسار عليها، فهو عندهم المؤمن، ومن خالفها فهو الكافر أو الفاسق، بل ربما جعل ذلك المبتدع طائفته هم أهل السنة والجماعة، ومن خالفها فهو من أهل البدعَّ.

والتقليد هو في الحقيقة من نتائج الجهل وآثاره، ومن الجهل ينشأ التقليد، والبدع تروج على المسلمين في سوق التقليد والجهل... وقد وجد البعض أن كلاً من التقليد

$$
\begin{aligned}
& \text { ' - سنن الدارمي، /90/9، وجامع بيان العلم وفضله / 19 19. }
\end{aligned}
$$

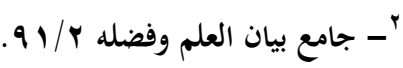

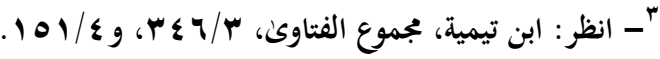


والبدعة له علاقة بالآخر لأسباب كثيرة'، فالصلة وثيقة بين البدعة والتقليد.

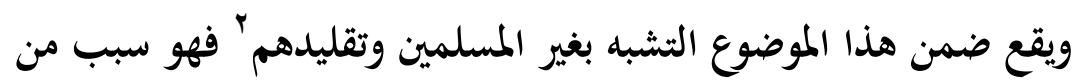

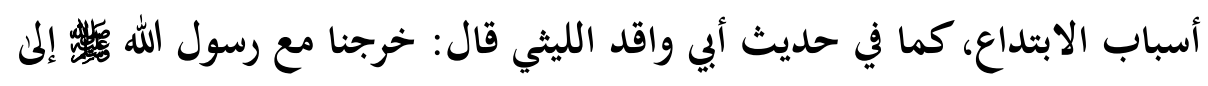

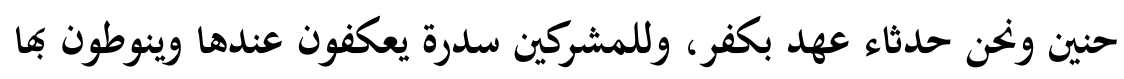

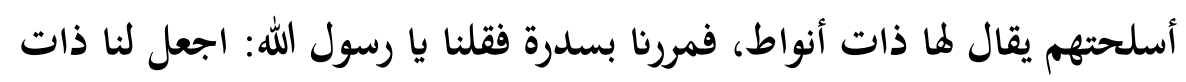

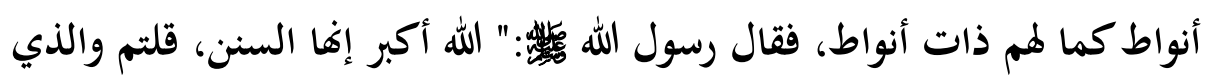

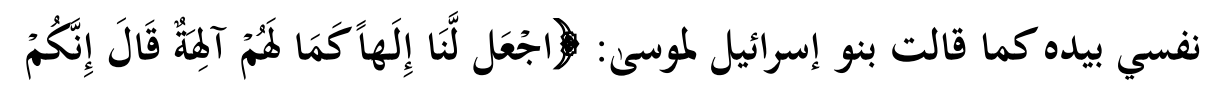

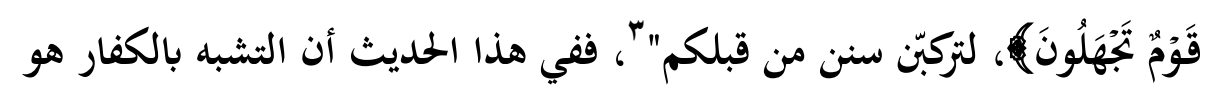

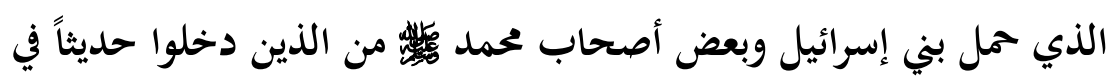

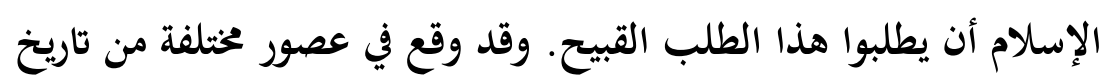

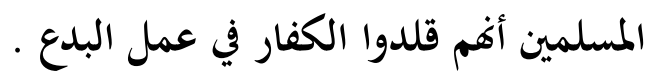

خامسا - إتباع العادة والعرف:

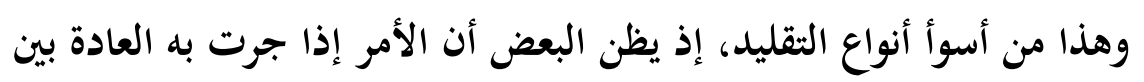

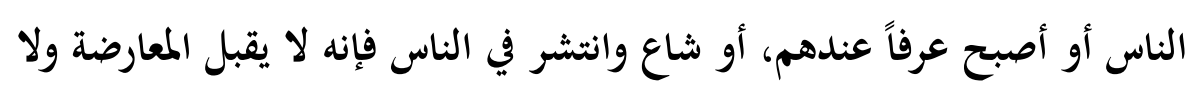
يتطرق إليه النقض.

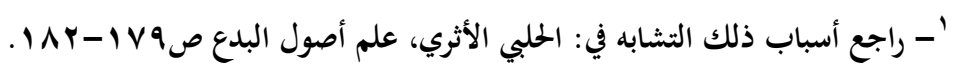

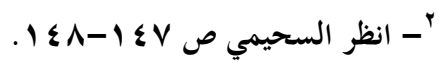

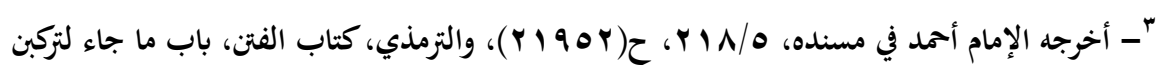

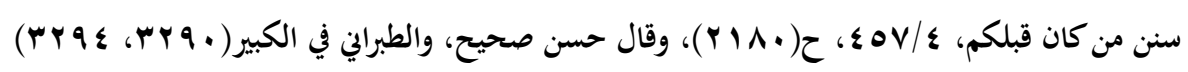

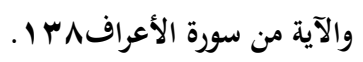


بل مما يزيد الأمر سوءا أن يعتقد أن مجرد الاعتياد على الفعل وكونه أصبح

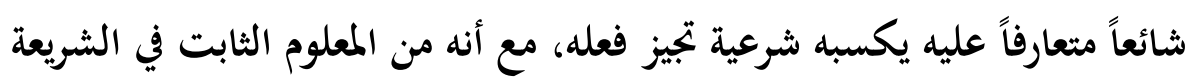

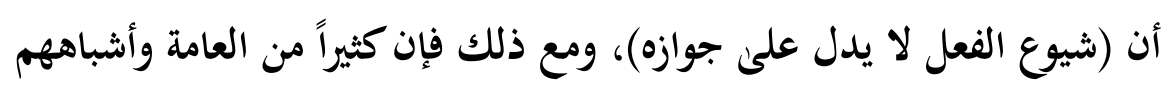
يعتنقون كثيراً من البدع على أفها سنن بسبب عمومها وشهرتحا واستدامة مبتدعيها

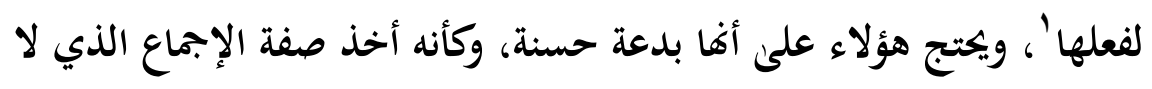
تصح مخالفته.

ومثال ذلك الأيام المخحصة بنوع من العبادات المبتدعة، فيحتج المبتدع بأن

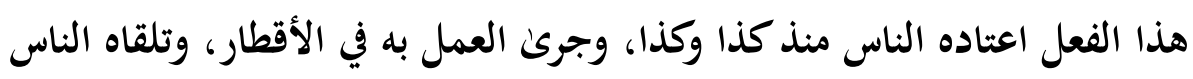

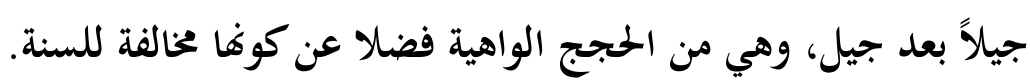

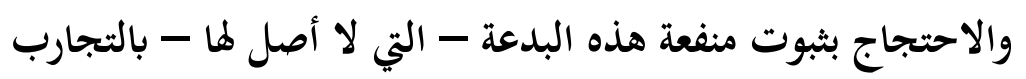

والأقيسة،

أن التصميم على إتباع العوائد وإن فسدت أو كانت مخالفة للحق، سبب من

$$
\begin{aligned}
& \text { أسباب انتشار البدع'. } \\
& \text { سادسا - الفتوئ بغير علم: }
\end{aligned}
$$

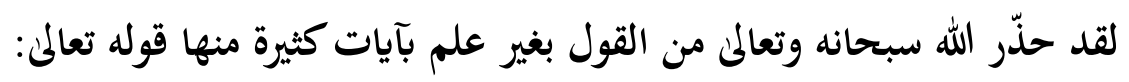

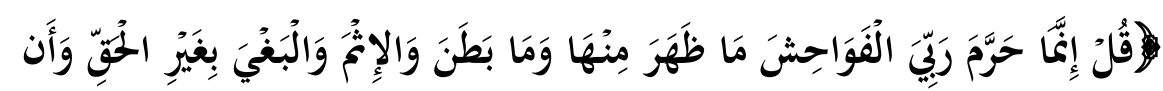

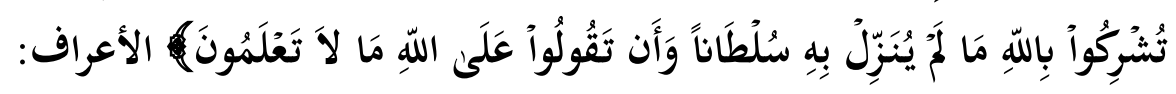

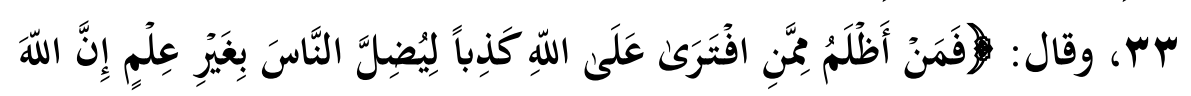

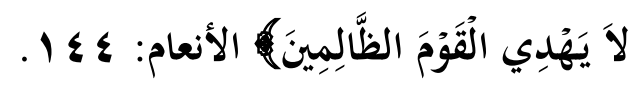


وقد وردت أحاديث تحذّر من الفتوى أو الحكم بغير علم، وخاصة فيما يتعلق

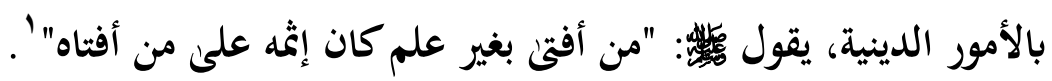
وقال عرف الحق فقضى به...، ورجل عرف الحقى فجار في الحكم فهو في النار، ورجل قضى للناس على جهل فهو في النار"'

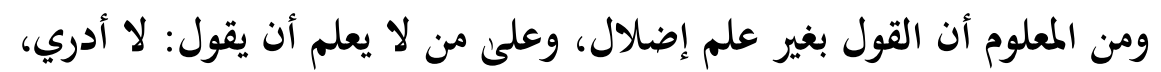
أو أن يسأل غيره، أو يطلب مهلة ليتبين وجه الحق، وكان إنس

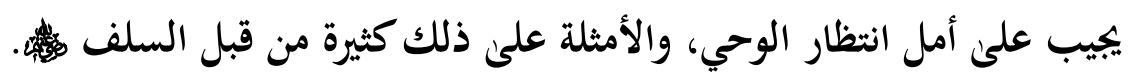

فإذا مارس الجاهل العلم وأفتن في الدين وقع في البدعة قاصداً أو غير قاصد،

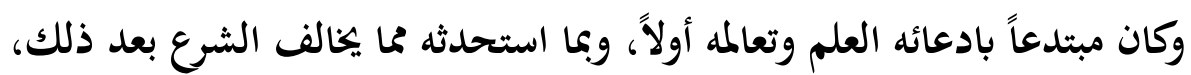
وانتشار ذلك سبب في قبض العلم، كما قال ينتزعه من العباد، ولكن يقبض العلم بقبض العلماء، حتن إذا لم يبق عالم اتخذ

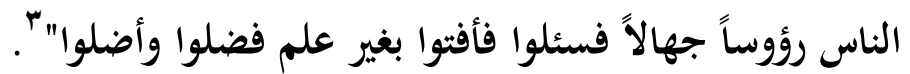

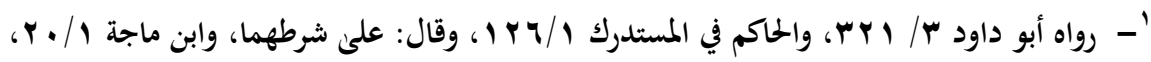
والدارمي ح ( 171).

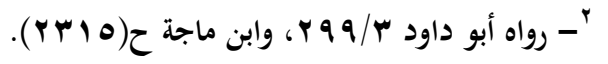

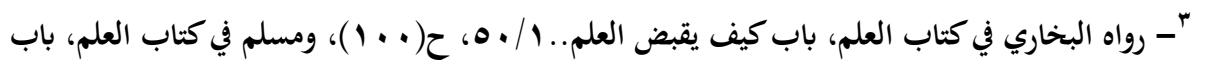

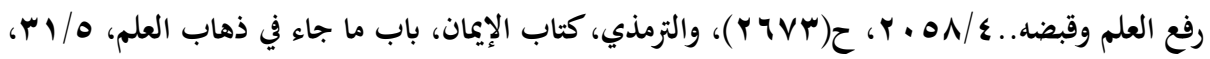

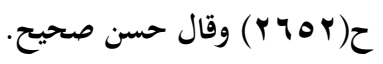


وقد يكون المبتدع من ذوي الفصاحة والبيان مع جهله بالعلم الشرعي، كما

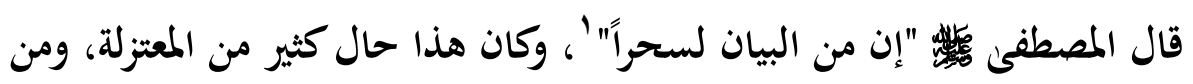

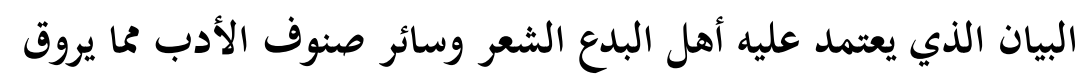

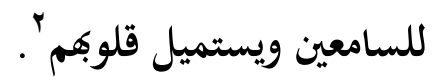

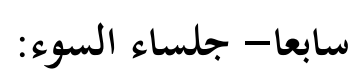

إن مخالطة أهل الشر ومجالستهم والاستماع إليهم من الأسباب الحطيرة التي

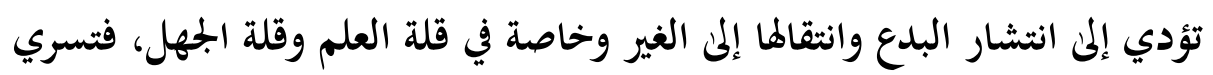

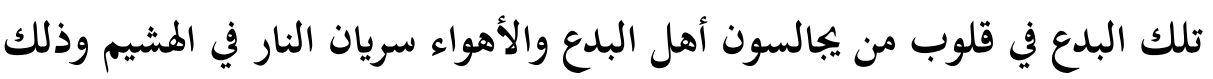
لأفم ليست عندهم الحصانة التي تحميهم من ذلك، وبمرور الوقت يعتاد عليها،

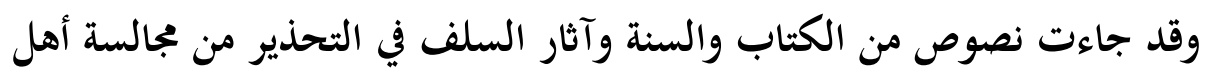

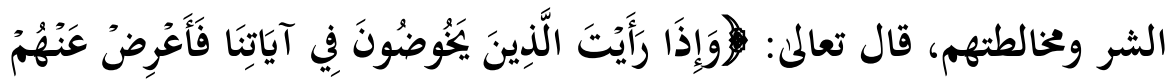

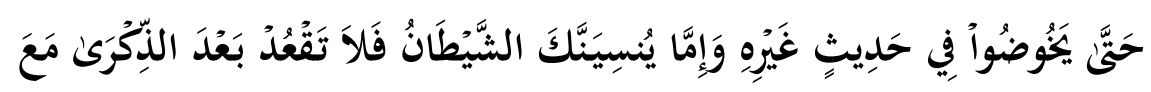

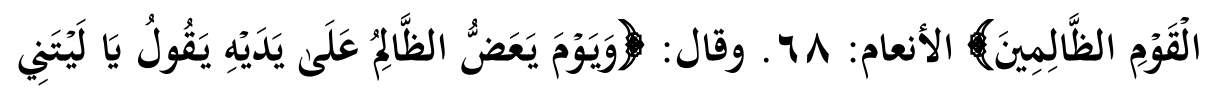

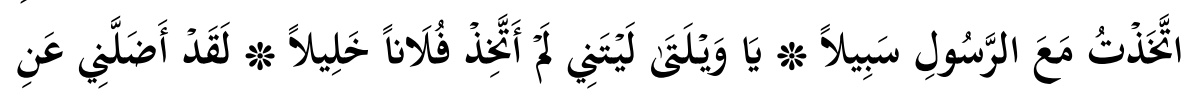

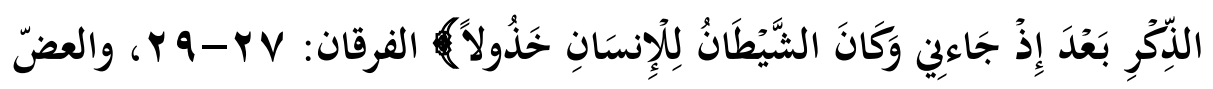

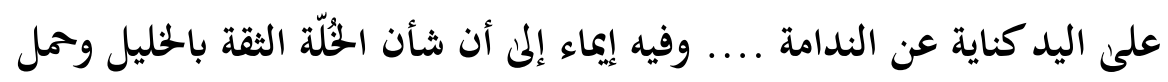

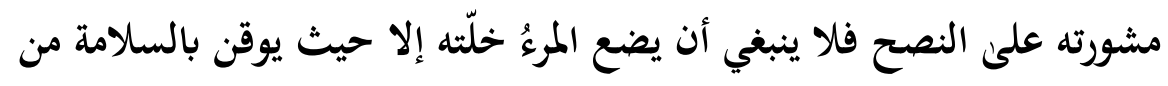
إشارات السوء"ب

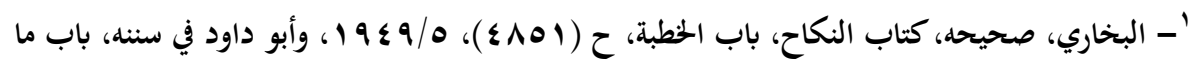

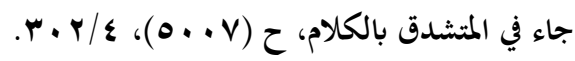

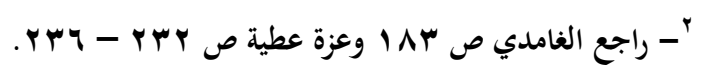

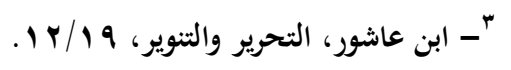


وقد مثل الرسول الصالح والجليس السوء كحامل المسك ونافخ الكير، فحامل المسك إما أن يحذيك

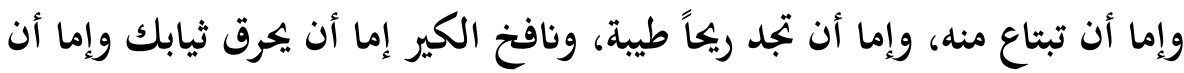
تجد ريحاً خبيثة"'، قال الحافظ ابن حجر : وفي الحديث النهي عن مجالسة من يتأذى

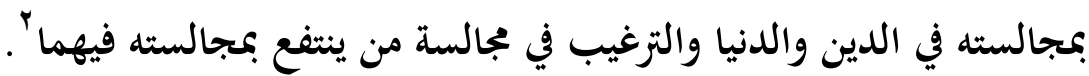
ويدخل ضمن ذلك احتفاء المبتدعة مع بعضهم وتعاوفم فيما بينهم وهذا سبب قوي في انتشار البدعَّ. ثامنا- إشاعة البدع من أعداء الإسلام وهذا السبب قد أغفله كثير ممن كتبوا في أسباب البدع، علماً أن لأعداء الإسلام أثراً كبيراً في انتشار البدع القولية والعملية والاعتقادية. لقد واجه الإسلام منذ فجر الدعوة تيارات معادية كثيرة، حاولت صد صد الإسلام بشتى الطرق، ولما انتشر الإسلام بفعل الفتوحات قامت بعض الجهات التي فشلت في رد الإسلام عسكرياً - وانتصر المسلمون عليهم - باتباع طريقة أخرىن غير المواجهة العسكرية وهو القضاء على الإسلام باسم الإسلام عن طريق تشويهه وصد الناس عنه، فنظاهروا بالإسلام ودخلوا مع أهله بنيات خبيثة، وكان من أوائل هؤلاء اليهود الذين كان قصدهم تفريق المسلمين وتشويه عقائدهم، وعن طريقهم ظهرت بدعة عبد الله بن سبأ اليهودي التي شقت صفوف المسلمين قديماً وحديثاً، وما أن دخلت جيوش المسلمين في فارس حتى ظهرت فرقة (الشعوبية)

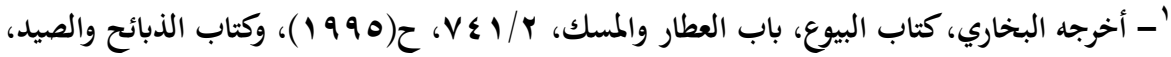

$$
\begin{aligned}
& \text { / }
\end{aligned}
$$

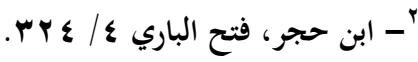

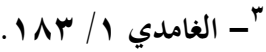


التي حاولت تشويه صورة العرب والمسلمين، وباسم الإسلام ظهرت حركات كثيرة لهم بدع كثيرة، المراد منها تحريف الدين والقضاء عليه، وهذا ما نجده في حركة الزندقة والباطنية وإخوان الصفا والقرامطة قديماً، وفي البهائية والقاديانية حديثاً، وكل هؤلاء لهم ارتباط بجهات غير مسلمة تمدّهم مادياً ومعنوياً، ومن علامات

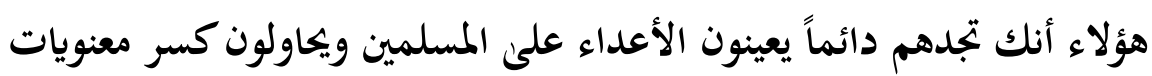
المسلمين، وقد أظهر هؤلاء في القديم والحديث بدعاً وخصوصاً في جانب العقائد تصل إلى حد الثرك والعياذ بالله. 
المبحث الثاني- أضرار البدعة وآثار من منظور القرآن الكريم

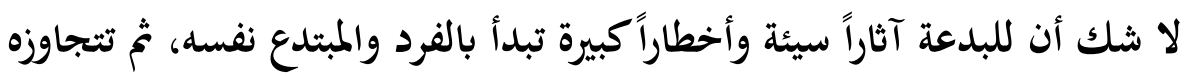
إلمى الأمة كلها، ويكن عرض هذه الأضرار على هذا الاعتبار.

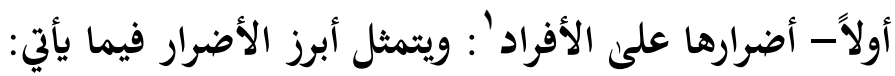

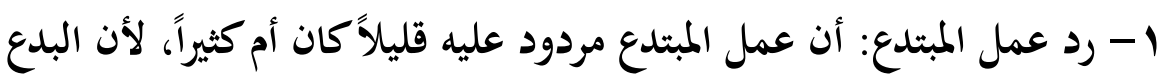
من المحدثات وكل بدعة ضلالة وكل ضلالة في النار، ولا يمكن أن ننصور قبول

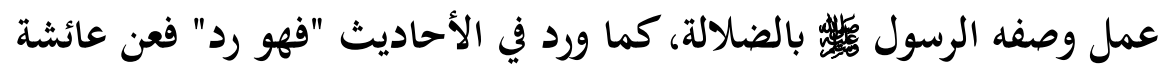

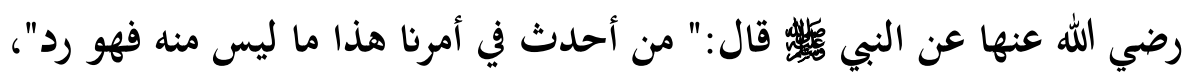
وفي رواية مسلم:" من عمل عملا ليس عليه أمرنا فهو رد"، وفي رواية البخاري

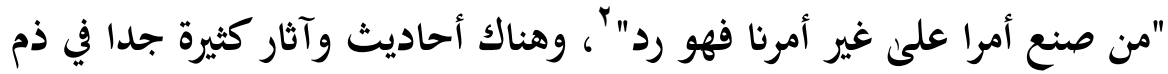
البدعة وصاحبها

. Y - بعد المبتدع عن الله لأنه أعطى نفسه حق التشريع وجعل نفسه نداً لله، والتشريع من حق الله سبحانه وتعالمى، وكأنه نظر إلى الدين ناقصاً ليكمله، والله

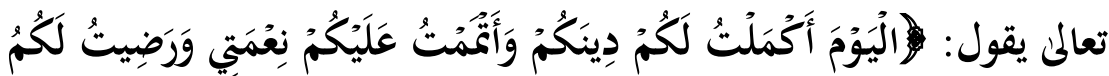

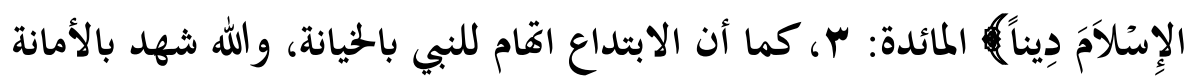
وصدق التبليغ كما مرّ ذكره، فمن كان بمذه الحال والصفة فهو بعيد كل البعد عن

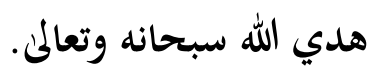

$$
\text { '- - راجع: القرني عائض، البدعة وأثرها في الرواية والدراية ص ساج. }
$$

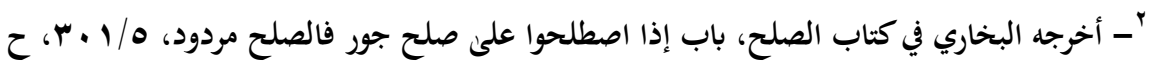

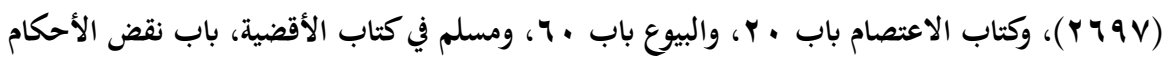

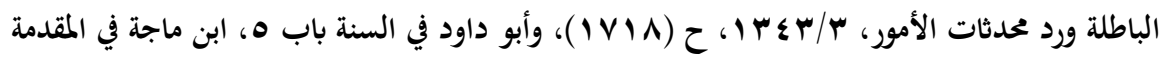


r- عدم قبول شهادته وروايته: فقد أجمع أهل العلم على عدم قبول شهادة الذي يكفر ببدعته، كالفرق الباطنية وغلاة الجهمية والفلاسفة الدهرية، واختلف العلماء في شهادة من لايكفر ببدعته، مع الاتفاق على رد رواية المستحل للكذب فالشافعي وغيره من السلف يقول: "أقبل شهادة أهل الأهواء إلا الخطابية" ، وإنما لهادئ

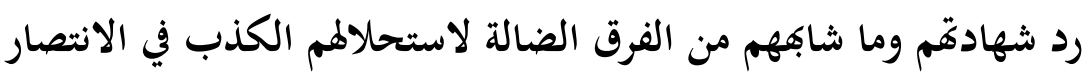

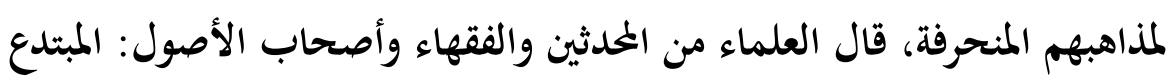
الذي يكفر ببدعته لا تقبل روايته بالاتفاق. وأما الذي لا يكفر بها فاختلفوا في روايته، فمنهم من ردها مطلقا لفسقه ولا ينفعه التأويل، ومنهم من قبلها إذا لم يكن ليكن ممن يستحل الكذب في نصرة مذهبه أو لأهل مذهبه، واختلفوا إذا كان داعية

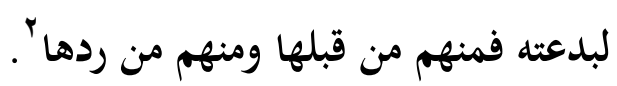
ع - يضاعف له الوزر: فالمبتدع عليه إثم بدعته، ووزر من عمل بها إلمى يوم القيامة،

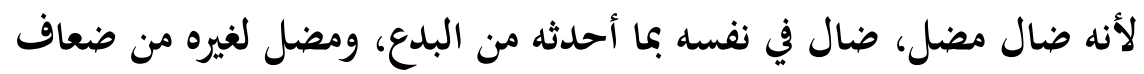

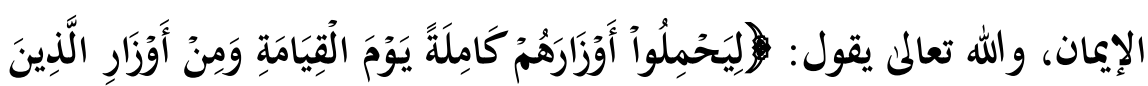

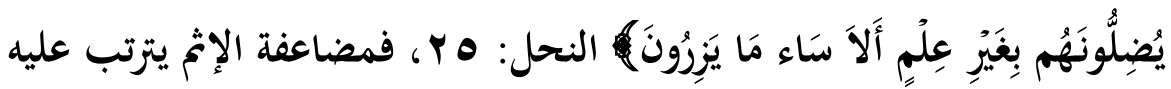
مضاعفة الوزر، ولذلك استحق المبتدع مضاعفة العقوبة، فقد جاء في الحديث الشريف: "...ومن سن سنة سيئة كان عليه وزرها ووزر من عمل بها إلى يوم

' '- أبو الحسن الأشعري، مقالات الإسلاميين Vo/ V، والشهرستاني في الملل والنحل / V9/1.

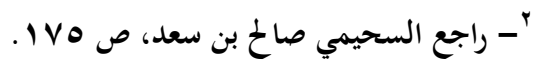




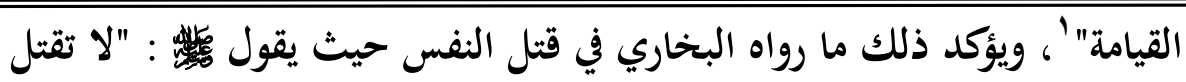

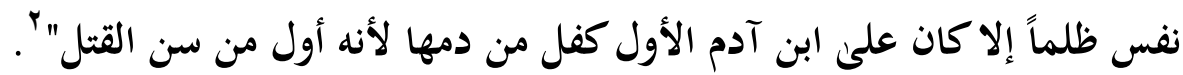

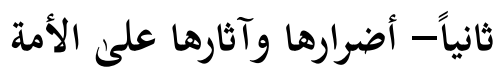

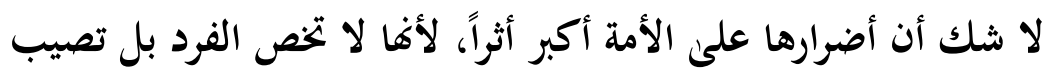

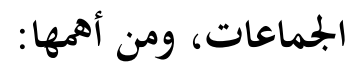

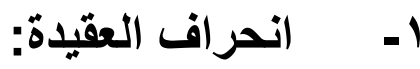

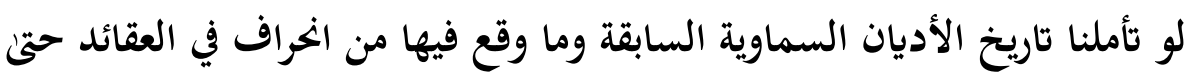
وصلت حد الكفر، لوجدنا أن البدع كانت الطريق الموصل إلى ذلك، مثل الغلو في

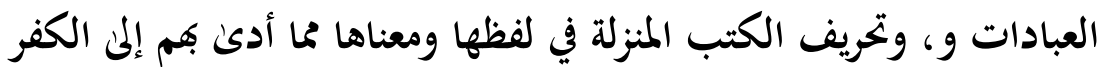
والإشراك بالله، فوصفوه بما لا يليق من الأبوة والبنوة وجعلوا له أندادا ونظراء. وكانت بدعة اليهود في التقصير والتفريط في الحقى، وبدعة النصارئ في الغلو

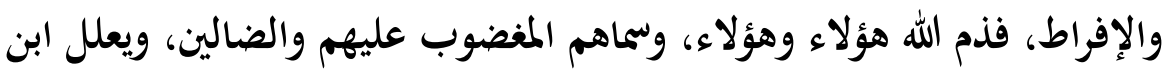
تيمية ذلك فيقول:" فأما وسم اليهود بالغضب والنصارئ بالضلال، فله أساب

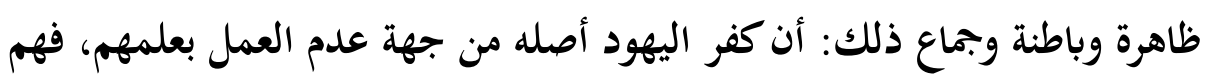

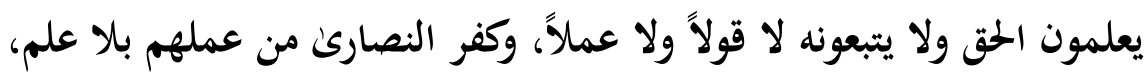

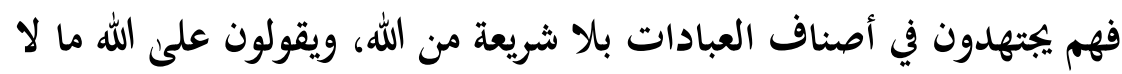

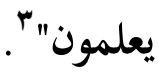

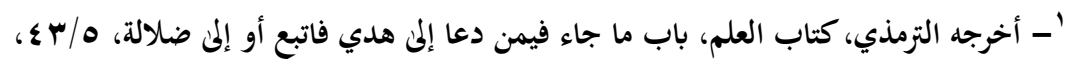

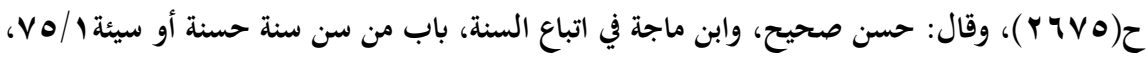

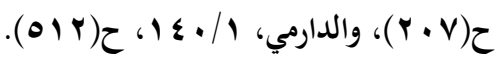

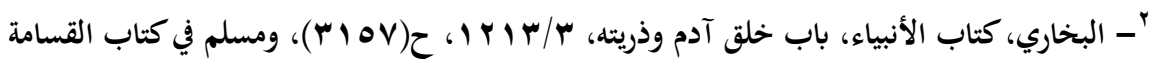

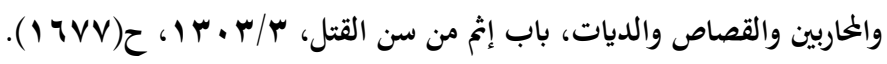

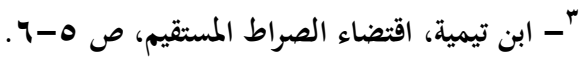




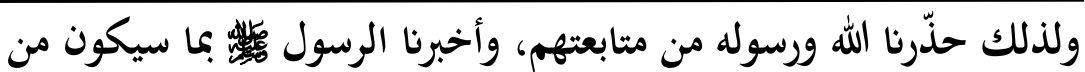
متابعتهم فقال: "لتتبعن سنن من قبلكم شبرا بشبر وذراعا بذراع، حتى لو دخلوا

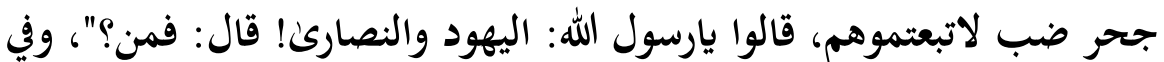
رواية: فقيل يا رسول الله كفارس والروم؟ قال: ومن الناس إلا أولئك" . فأخبر الرسول أمور كثيرة حتى تصل إلم شدة في المتابعة كما وصفها الحديث، وهذا ما حصل ويحصل فيما نرىن من تقليد المسلمين لمم في كل شيء، كما حصل أن بعض المبتدعة وصلوا إلم حد الكفر مع ادعائهم الإسلام، كبدع العقائد المعروفة من المشبهة والمعطلة والجبرية والقدرية في القديم، وفي بدعة القاديانية والبهائية. ولا شك أن منهم من ضلّ على علم فأشبه اليهود، ومنهم من أضلهم علماؤهم فأشبه بذلك النصارىن. فمن تشبّه من هذه الأمة باليهود والنصارىن في إفراطهم أو تفريطهم فقد شابكهم، كالخوارج المارقين من الإسلام الذين خرجوا على المسلمين، وكان قتالمم بأمر من

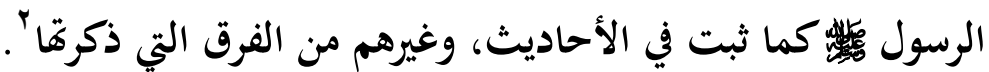
وقد يغتر البعض بما لدى هذه الفرق من الطقوس وبعض العبادات الإسلامية، فهي لا قيمة لما بجانب ما لديهم من تفريط فهي كالسراب الذي يظنه الرائي ماءً وهو ليس بشي.

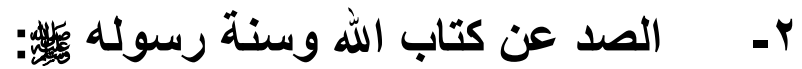

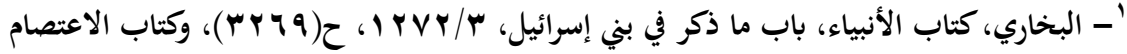

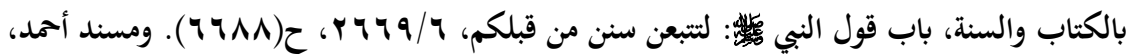

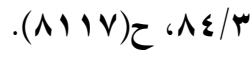

$$
\begin{aligned}
& \text { †- راجع: السحيمي ص } 100 .
\end{aligned}
$$


وذلك لأغم اشتغلوا بالجدل والاعتراض فضعفت همتهم عن تحصيل العلم

$$
\text { الواجب، يقول أبو شامة: }
$$

"ثم تفاقم الأمر حتن صار كثير منهم لا يرون الاشتغال بعلوم القرآن والحديث، ويرون أن ما هم عليه هو الذي ينبغي المواظبة عليه، فبدّلوا الطيب خبيثاً كما قال

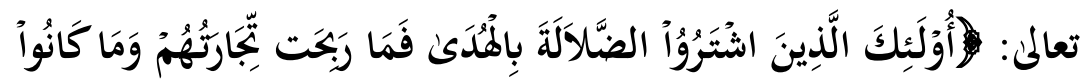

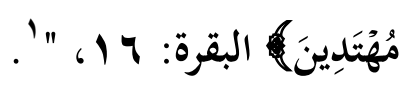

ويندرج تحت ذلك التحاكم إلى العقل والتهاون بالنقل، فهم مقصرون في علم الرواية معرضون عن الحديث متعمقون في الكلام ودقائقه.

ويترتب على الصد عن الكتاب والسنة والقول على الله بغير علم، وهو ما

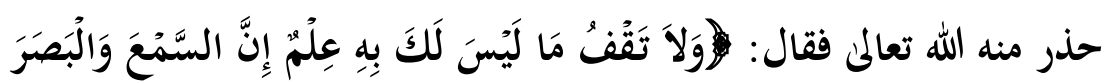

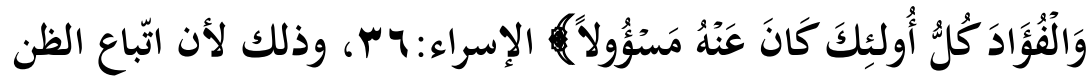
والتخمين في شرع الله هو باب إلمى الضلال، بل وصفه الله من أكثر الأمور ظلماً

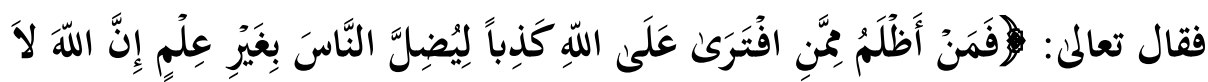

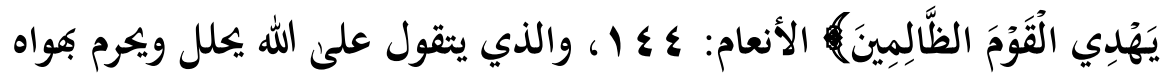
وينسبه إلى الله كما فعل المشركون في الجحاهلية حين حرمّوا ونسبوه إلى الله، "ونسبة الباطل إلى الله تعالمى عن ذلك: غرر وخديعة لعامة الناس، ولو كانت نسبة قول هذا

$$
\text { المنقول إلى نفسه لكان أيسر، ولكنه جعل هذا القول من الشرع.." ". }
$$

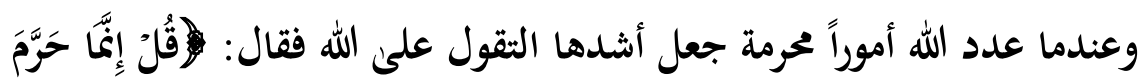

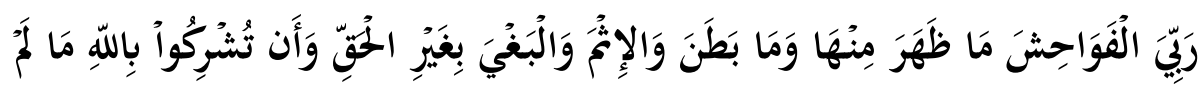

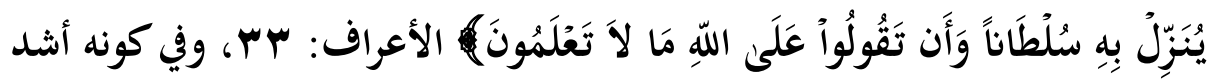

$$
\begin{aligned}
& \text { ' - 'أبو شامة، الباعث على إنكار البدع والحوادث، ص OV }
\end{aligned}
$$

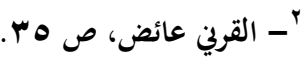


الخحرات لأنه يمتنع الكذب على الله، ونسبته إلمى ما لا يليق به، وتغيير دينه وتبديله، ... فليس في أجناس الحرمات أعظم وأشد إثماً، وعليه أسست البدع لهئ

والضلالات، فكل بدعة مضلة في الدين أساسها القول على الله بلا علم.. '. وقد حذّر الله سبحانه من نسبة من يتقول بغير علم إليه فقال: الِوَلاَ تَقُولُوُاً

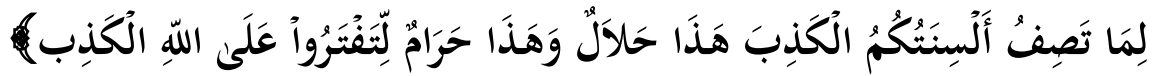
النحل: 71 1)، أي "لا تسموا ما لم يأتكم حله ولا حرمته عن الله تعالم ورسوله صلى الله عليه وسلم حلالاً ولا حراماً فنكونوا كاذبين على الله تعالمى لأن مدار الحل والحرمة ليس إلا حُكَمَهُ سبحانه"

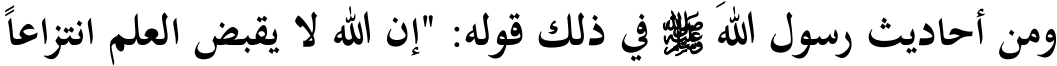

ينتزعه من الناس، ولكن يقبض العلم بقبض العلماء، حتن إذا لم يبق عالماً، اتخذ

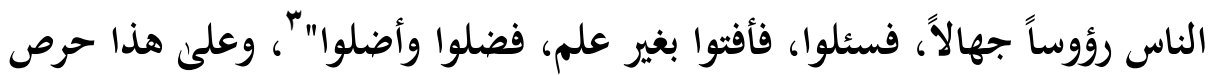
السلف على حفظ العلم واستحضاره والاستدلال به ونشره ليقطعوا الطريق على المبتدعة.

r- إماتة السنن ومضادتها للشريعة المطهرة كلما ظهرت بدعة أماتت سنة من السنن، لأن البدعة أساسا ما ظهرت إلهادئه إلا بعد ترك سنة، وما أشيعت إلا بعد تخلّي الناس عن السنة الصحيحة، وفساد نفوسهم،

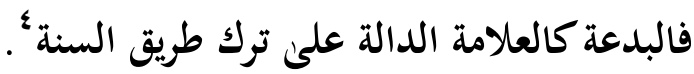

$$
\begin{aligned}
& \text { ' - السحيمي، ص 10N-10V. } \\
& \text { r الآلوسي، تفسيره، }
\end{aligned}
$$

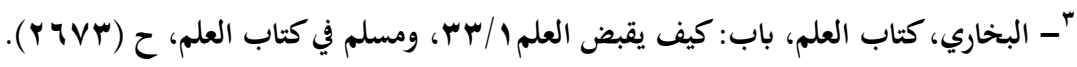

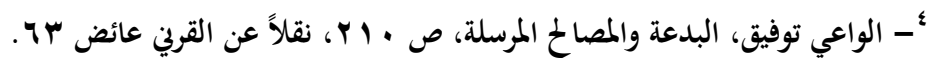


وكما قال القائل: ما رأيت إسرافا إلا وبجانبه حق مضيع، إذا رأيت إسرافاً في جانب لابد أن تجد تقتيراً في جانب آخر، فالإنسان إذا وضع طاقته في البدعة فلا

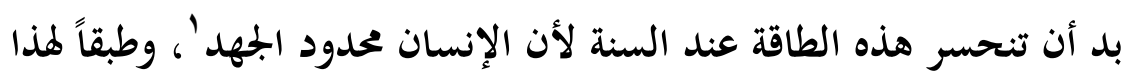
القانون تجد المبتدعة ينشطون في البدع، وفي أمور السنة يضعفون ويفترون.

$$
\text { ع - تفريق الأمة وتززيق وحدتما }
$$

وهي من أكبر الأخطار التي أصابت الأمة بسبب البدع، حتى صارت الأمة شيعا وأحزاباً يعادي بعضها بعضا ويستحل بعضهم دماء بعض، وتنتشر بينهم

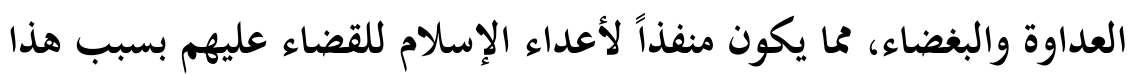
التفرق، والآيات القرآنية في ذم التفرق كثيرة سبق ذكرها عند الكلام عن ذم

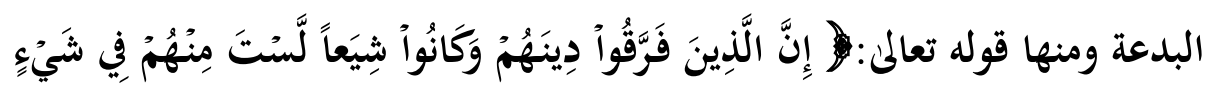

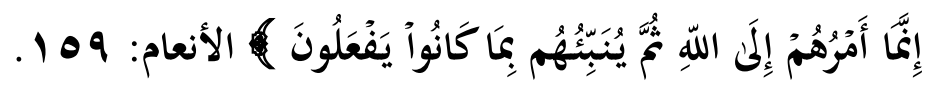
والتفرق نتيجة حتمية للبدع، وذلك لأن أهل البدعة ينتصرون لبدعهم ومحدثاتم، الأمر الذي يحتم وجود من يقوم بالانتصار للسنة والذب عنها وتخليصها لئه من شوائب البدع والحرافات، ومن ثم ينشأ الصراع بين أفراد الأمة ويصل بهم الحال

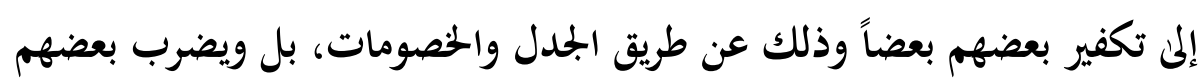

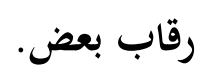

وذلك لأن الوقوف عند السنن يجمع الأمة على كلمة واحدة، ويجعلها صفاً

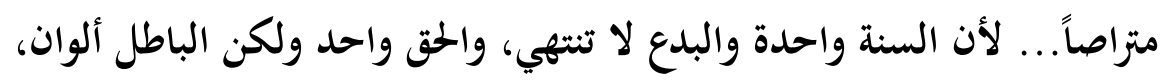

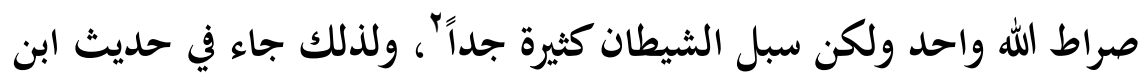




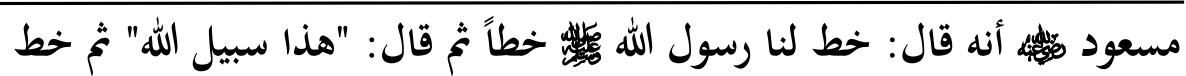

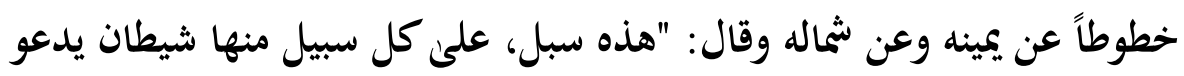

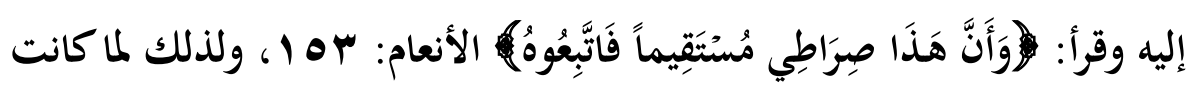

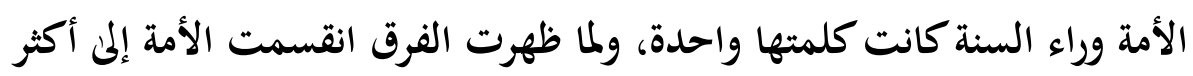

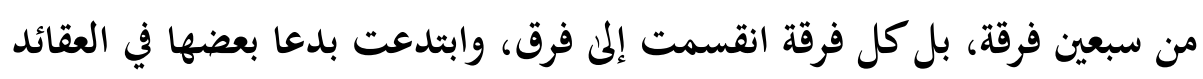

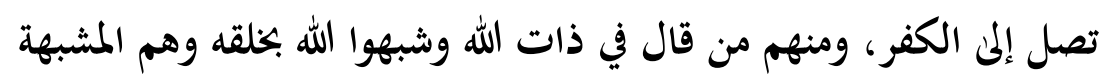

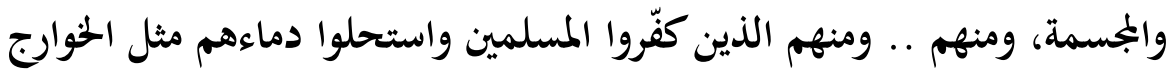

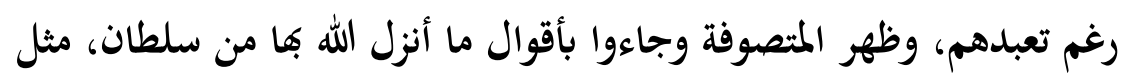

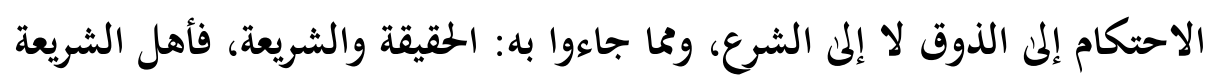

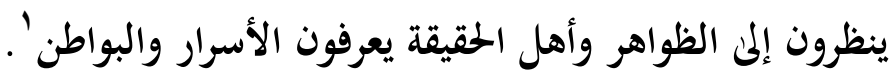

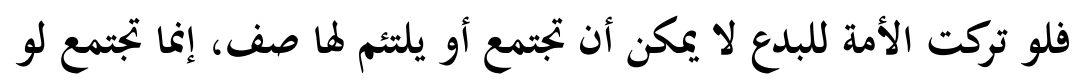
وقفت خلف رسول الله

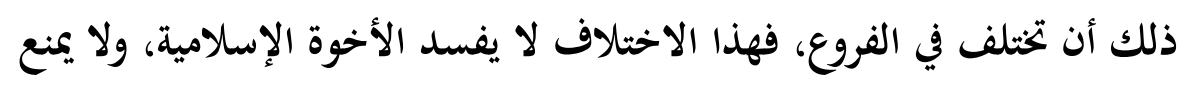

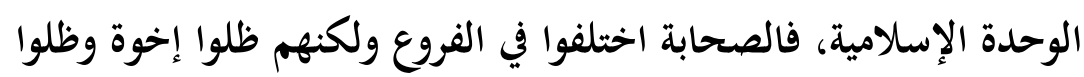
مسلمين. وقد حذر الله من الفتن وبين أن خطرها يعم إذا أهمل المسلمون واجب الأمر

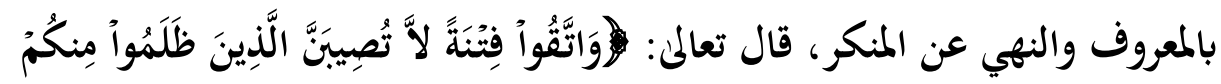

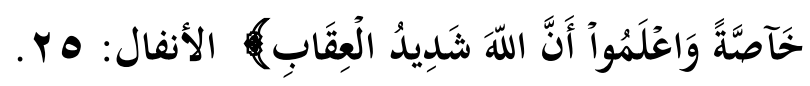

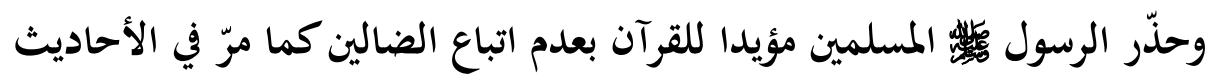

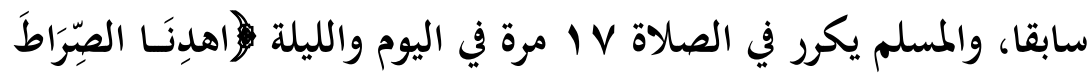

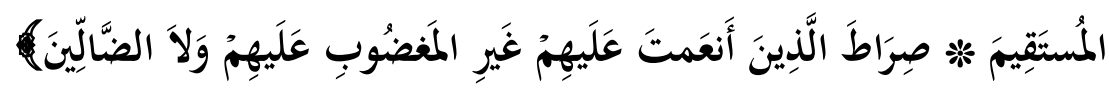


الفاتحة: Y-V، وحين وقعت البدع بين المسلمين في الاعتقاد وفي الأقوال

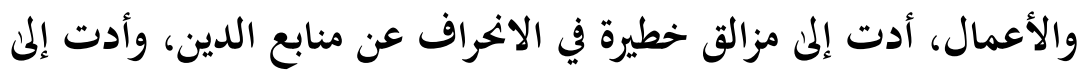
الانفصام بين المسلم ومصادره في التشريع.

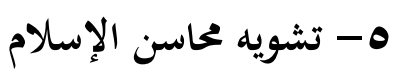

الدين الإسلامي كله محاسن، ولكن البدع تشوه الدين وتعكر صفوه،

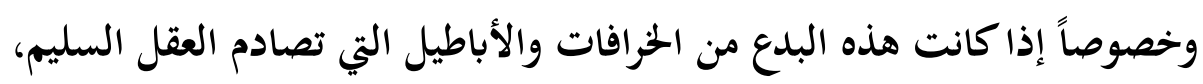

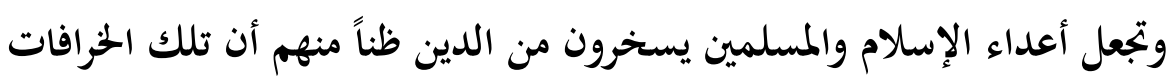

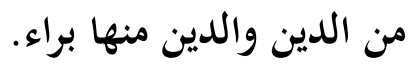

ويتجلى هذا فيمن يصور الدين تصويراً يأباه ما للدين من جمال وجلال، وكثيراً الداء ما تنشر البدع وتأخذ مكانة الدين في النفوس، وتصير هي الدين المتبع عند الناس الدياه وبقدر ذيوعها يكون إندراس الدين' .

وهذا التشويه يكون سبب في إعراض الناس عن الدين لأفم يظنون أن هذا

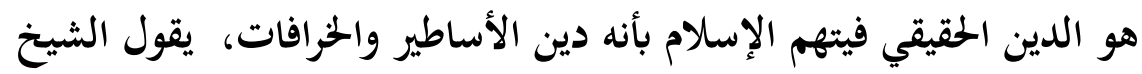

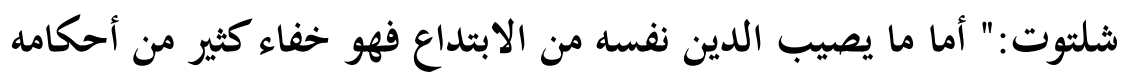
وتشويه جماله: - مالم: والأول: سبب من أسباب اندراس الشرائع.

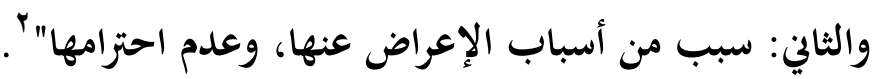

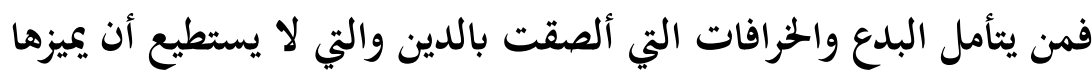
غير المسلم فإنه لا يفكر في الدخول فيه لأنه يحكم على الإسلام من خلال الئل

$$
\text { ' - ' الحلبي الأثري ص MAV }
$$


المسلمين وتصرفاقم وبذلك تكون البدعة من هنا عائقاً في نشر الإسلام بل وصد الناس عنه. ج- الوقوع في الغلو وتعسير الدين الدين جاء ميسرا للناس، والمبتدعون يخرجون بهذا الدين عن طبيعته السمحة الميسرة، فهم يشقون عليهم ويكلفوغم فوق طاقتهم، وكأفم يريدون إعادة آصار الأديان السابقة وتكاليفها المرهقة، وقد ورد وصف الرسول في القرآن في قوله تعالمَ

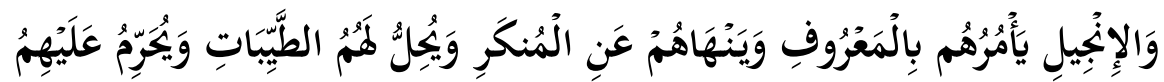

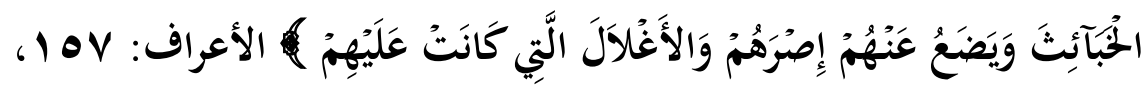

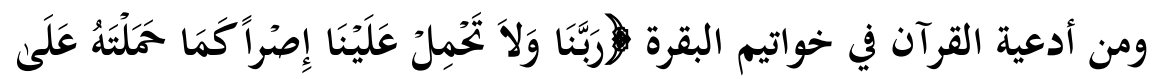

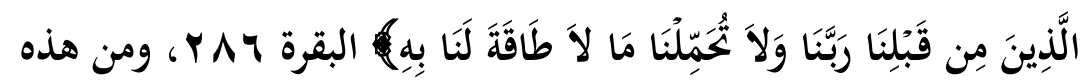

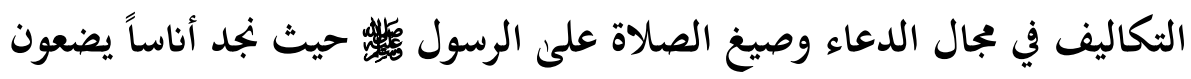

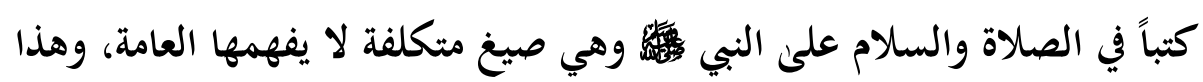
شأن أكثر الأوراد والأحزاب، ويكفينا ما ورد في القرآن والسنة. وهكذا تكون النتيجة أن الناس يستثقلون تكاليف الدين ويضيقون بما

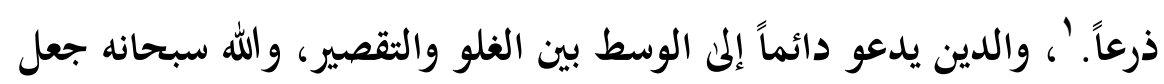
التكاليف الشرعية بمقدور كل إنسان، ولم يضعها من أجل طائفة تريد التضييق

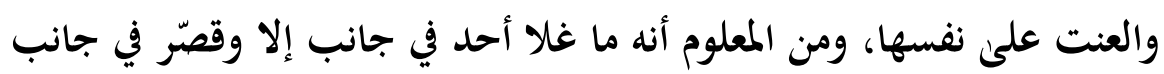
آخر.

والغلو داء أصاب الأمم في القديم ومنهم اليهود والنصارين، وجاءت نصوص كثيرة تذم الغلو والتعصب داعية إلى الوسط، والوسطية هي العدل، وقد جمع 
الرسول

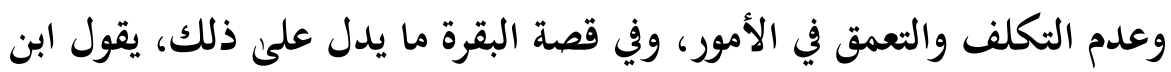

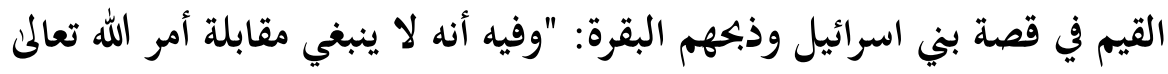

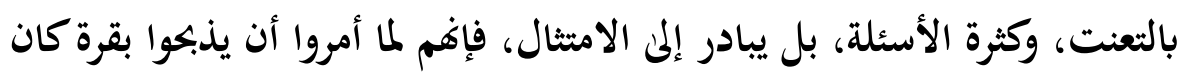

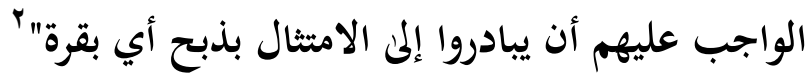

- V

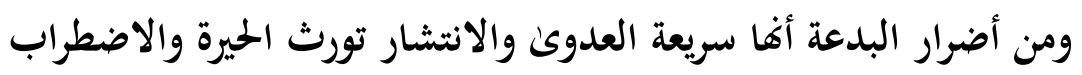

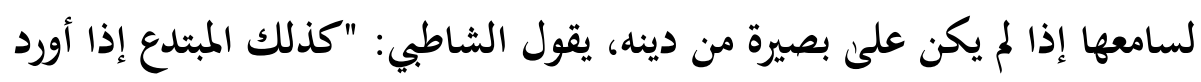

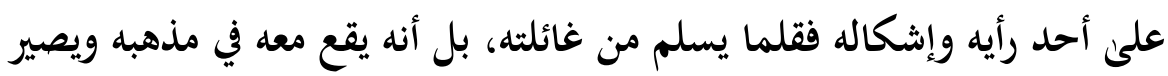

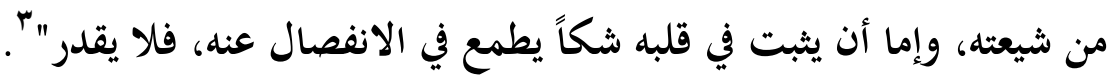

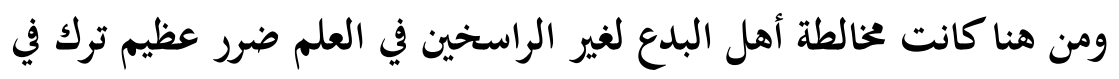

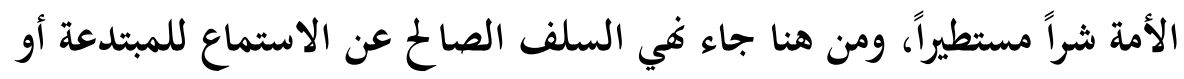

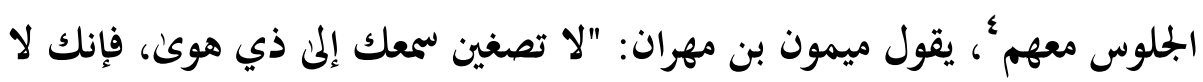

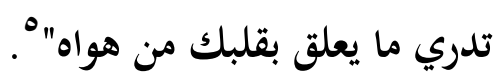
وعادة الذي يدعو إلم أمر لا بد وأن يستعمل كل وسل وسائل الإقناع، ولذلك نجح بعضهم في إدخال كثير من البدع بزخرفة الكلام وتنميقه.

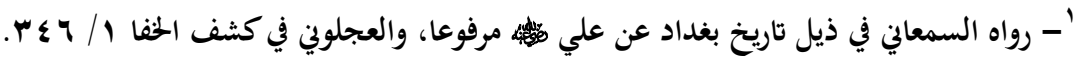

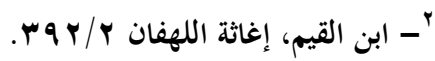

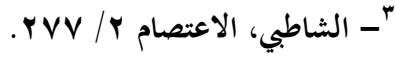

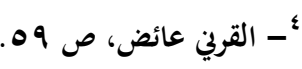

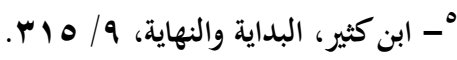


وإذا ما دخل المرء في البدعة اختلطت عليه الأمور والتبس عليه الحق بالباطل، واستمرأ الجحدل والخصومة ولو في توافه الأمور، واستعظم الصغير، واستصغر لهر

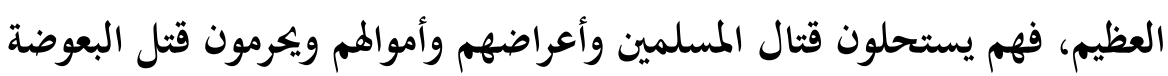
حتن التبس عليهم الأمر وحلّ بمم ما حل بأهل الكتاب فتقربوا إلى الله بما لا

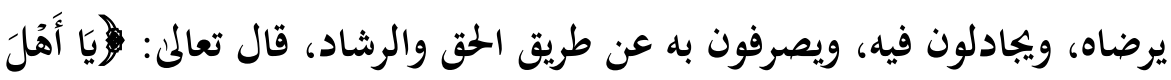

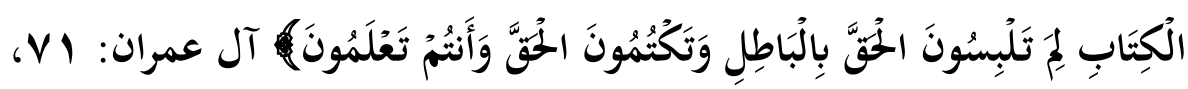

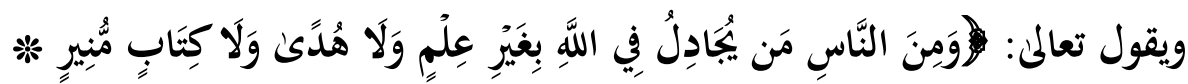

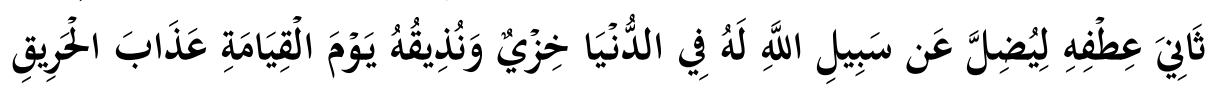

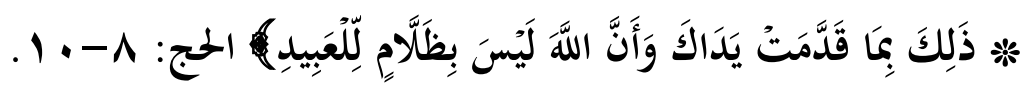

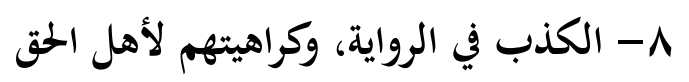

إن أهل البدع لا يتورعون في التزوير والكذب على الله ورسوله، وربما ينتحلون

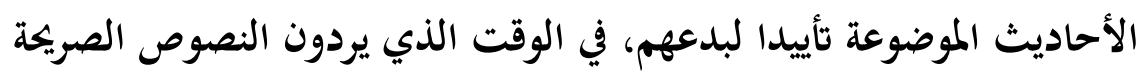
الصحيحة التي تنقض أقوالمم وترد عليه وهم لايرون هناك فائدة من علم الإسناد الذي قال عنه ابن المبارك رحمه الله: "الإسناد من الدين، ولولا أسناد لقال في السنة من شاء ما شاء"' . وأكثر المبتدعة لا يهتمون بالحديث وعلومه كما لا يهتمون بمنهج السلف في فهم القرآن الكريم بل يتعسفون في فهم النصوص ويلوون أعناقها كي توافق معتقداتم..

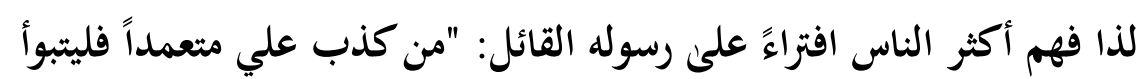
مقعده من النار"'

' - مقدمة صحيح مسلم، 10/1.

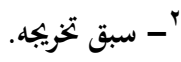


ومن أعظم مخاطر البدعة وآثارها أن أهل البدع ومروجيها يكرهون الحق وأهله ومتبعي الهدن، فيصفوفم بأوصاف لا تليق بمم، وهم أحق بتلك الأوصاف كما يقول المثل: "رمتني بدائها وانسلت".

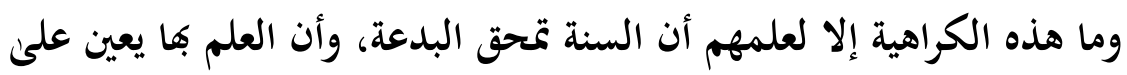
التفريق بينها وبين البدعة، بإذن الله' .

$$
\text { 9- تعطيل مواهب الأمة وقواها }
$$

فهي تصرفها عن مهمتها الأصيلة في تبليغ هذا الدين، وتصد عن كتاب الله

وسنة رسوله بالانشغال بالرد والجدل والاعتراض، كما تصرفها عن الابتكار في شؤون الدنيا لأن الناس إذا بذلوا جهودهم في الزيادة على الدين لن تبقى لهم طاقة للعمل للدنيا والابتكار فيها، وإذا تذكرنا تعريف البدعة وهو "طريقة في الدين

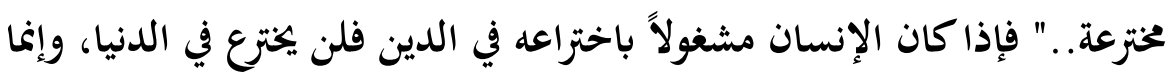

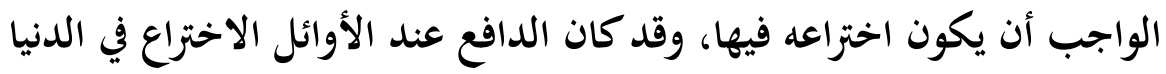
لأجل الدين، فمن ذلك علم الجبر عند الحوارزمي اخترعه لحل مسائل معينة في الوصية والميراث، وكانت علوم الدنيا عندهم متصلة بعلوم الدين، فابن رشد إند الدئ صاحب كناب الكليات في الطب كان قاضياً وهو صاحب كناب (بداية الجنتهد وفهاية المقتصد في الفقه). فالعلماء وقفوا عند النص والسنن في أمور الدين، وابتكروا واخترعوا في أمور

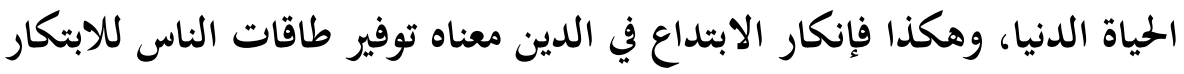

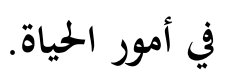


حاول البحث تتبع أسباب البدعة واستقراءها من الكتاب والسنة، كما حاول استقصاء الأضرار للبدعة وآثارها السلبية وتوصل البحث للنتائج الآتية: ا- إن البدعة بالمعنى الثرعي كلها مذمومة، ولها حكم عام "كل بدعة ضلالة"، أما على المعنن اللغوي فهناك بدعة حسنة، وبدعة سيئة.

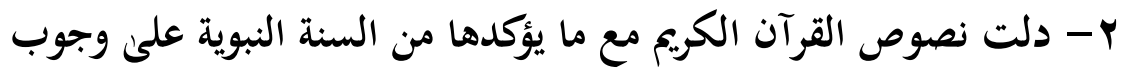
التمسك بالسنة واتباعها، فالخروج من الاتباع يوقع في الابتداع، كما دل على ذمها آثار السلف الصالح فضلا عن العقل الذي يرى أن البدع استدراك على الشريعة ورميها بالنقص والثقصير. ب- لظهور البدع أسباب كثيرة ومتعددة، ومتشابكة، في مقدمتها الجهل بنصوص الكتاب والسنة لعدم معرفة المبتدع لأساليب البيان وقصور فهمه باللغة، ومن ناحية السنة جهله في التمييز بين الأحاديث المقبولة والمردودة، وجهله بمصطلح الحديث دراية ورواية، وبمكانة السنة، وكذلك الجهل بمقاصد الشريعة، واتباع الهوىن بـ بهن المضل، واتباع المتشابه، والتقليد بأنواعه، واتباع العادة والعرف، وسكوت العلماء عليها، والفتوكن بغير علم، وصحبة السوء، والأدهى من ذلك البدع المتعمدة لتشويه صورة الإسلام. ع - للبدع أضرار وآثار على مستوكى الفرد والمجتمع، فمن الأول: رد العمل، وحجب التوبة، والبعد عن الله وتوفيقه، ورد شهادته وروايته، مع مضاعفة الوزر، أما أضرارها على المستوى الجماعي: فانحراف في العقيدة، ثم الصد عن كتاب الله، وإماتة السنة، فما ظهرت بدعة إلا وأماتت سنة، كما تؤدي لتفريق وحدة الأمة وتزيقها، وهي تشوّه محاسن الإسلام، وتوقع في الغلو بالدين وتعسيره، والبدعة 
I HAT

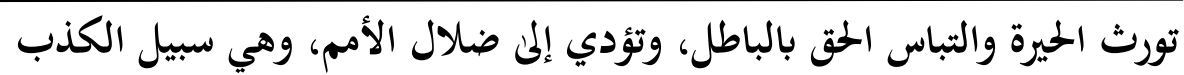
وكراهية الحق وأهله، وأخيرا تؤدي إلم تعطيل مواهب الأمة. 
(

الألباني، سلسلة الأحاديث الصحيحة، بيروت: المكتب الإسلامي، ط r

$.1 \% q 9$

الآجري، ححمد بن الحسين، الثريعة، تحقيق: محمد حامد الفقي، بيروت: دار

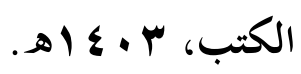

الآلوسي، شهاب الدين محمود، تفسير القرآن العظيم والسبع المثاين، بيروت: دار

$$
\text { إحياء التراث العربي، (د.ت ماثل) }
$$

ابن الأثير، ججد الدين أبو السعادات، النهاية في غريب الحديث والأثر، تحقيق: طاهر أحمد الزاوي، وححمود الطناجي، بيروت: دار إحياء التراث العربي. ابن تيمية، ججموع فتاوى شيخ الإسلام ابن تيمية، جمع وترتيب عبد الرحم بن عمدد ابن قاسم العاصمي وابنه، الرياض: إدارة البحوثالعلمية والإفتاء ، مج م اهـ. ابن تيمية، اقتضاء الصراط المستقيم، الرياض: مكتبة الرشد، ع ـ ع اهـ. ابن الجوزي، الموضوعات، تحقيق: عبد الرحمن عثمان، المدينة المنورة: المكتبة

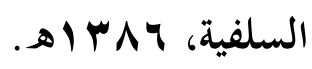

ابن حجر العسقلاني، أحمد بن علي، فتح الباري شرح صحيح البخاري، مصر: مكتبة الكليات الأزهرية، ع 9 أم م.

ابن رجب الحنبلي، جامع العلوم والحكم في شرح خمسين حديثا من جوامع الكلم، تحقيق: سيد إبراهيم، القاهرة: دار الحديث، ب9 99 ام. ابن عاشور، ححمد الطاهر، التحرير والتنوير، تونس: الدار التونسية للنشر، . $9 \wedge \varepsilon$ ابن عبد البر، جامع بيان العلم وفضله، بيروت: دار الفكر. 
ابن قيم الجوزية، إغاثة اللهفان من مصايد الشيطان، تحقيق: محمد حامد الفقي،

$$
\text { بيروت: دار المعرفة. }
$$

ابن قيم الجوزية، إعلام الموقعين عن رب العالمين، بيروت: دار الفكر، ط ؟ب، . 9 9VV

ابن قيم الجوزية، الطرق الحكمية في السياسة الشرعية، تحقيق: محمد حامد الفقي،

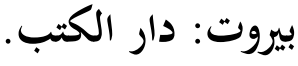
ابن كثير،ختصر تفسير ابن كثير لحممد علي الصابوني، بيروت: دار القلم، ط ه، .1919 ابن منظور، لسان العرب، بيروت: دار صادر.

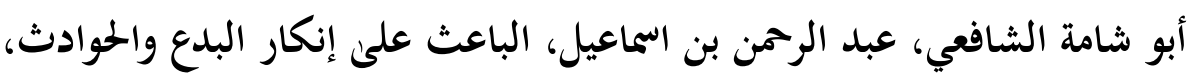

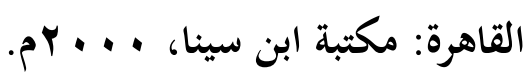
أبو نعيم الأصبهاني، حلية الأولياء وطبقات الأصفياء، بيروت: دار الكتاب العربي،

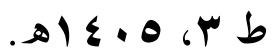
البغوي، الحسين بن مسعود، شح السنة، تحقيق: زهير الشاويش، وشعيب

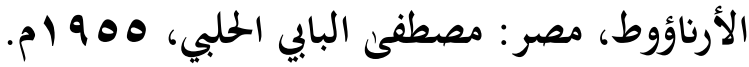

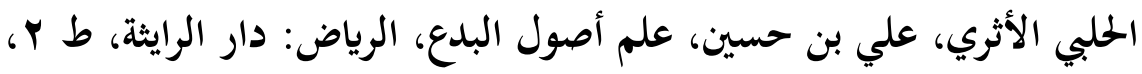
(1)

الخطيب البغدادي، شرف أصحاب الحديث، تحقيق: محمد سعيد الخطيب أوغلي،

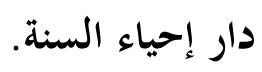
الزحيلي، وهبة، الثفسير المنير في العقيدة والثريعة والمنهج، دمشق: دار الفكر، إحية،

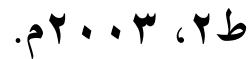


السحيمي، صالح بن سعد، تنبيه أولي الأبصار إلم كمال الدين وما في البدع من

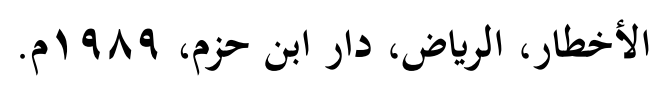

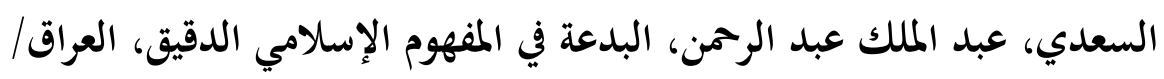

رمادي، مطبعة النواعير، ب 99 ام ام.

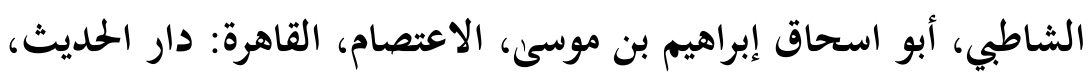

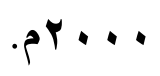

الشاطبي، أبو اسحاق إبراهيم بن موسى، الموافقات، تعليق: عبد الله دراز، بيروت:

$$
\text { دار المعرفة، (د.ت). }
$$

الثافعي، محمد بن أدريس، الرسالة، تحقيق: أحمد محمد شاكر، (د.ت)

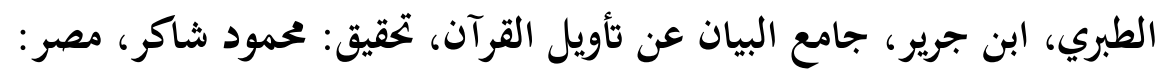

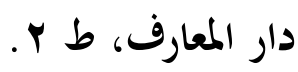

الطرطوشي، أبو بكر محمد بن الوليد، الحوادث والبدع، تحقيق: محمد الطيالسي، جدة: دار الأصفهاني.

العز بن عبد السلام، قواعد الأحكام في مصالح الأنام، بيروت: دار الكتب الكبام العلمية.

عزت علي عطية، البدعة تحديدها وموقف الإسلام منها، القاهرة: دار النهضة،

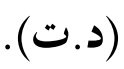

علي لن أبي العز الحنفي، شرح العقيدة الطحاوية، تحقيق: الألباني، دمشق: المكتب

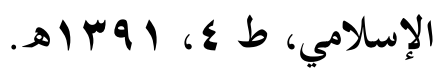

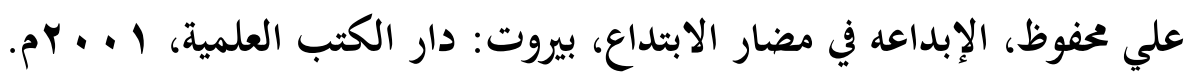

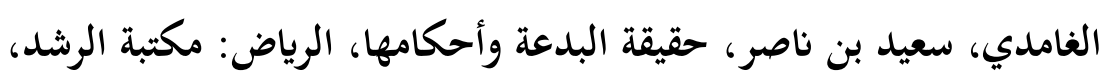


الغزالي، أبو حامد، إحياء علوم الدين، لبنان: دار المعرفة. القرافي، شهاب الدين، الفروق، بيروت: عالم الكتب، (د.ت).

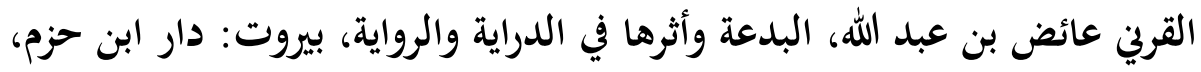
مY Th محمد رشيد رضا، تفسير المنار، بيروت: دار المعرفة، ط ץ، (د.ت).

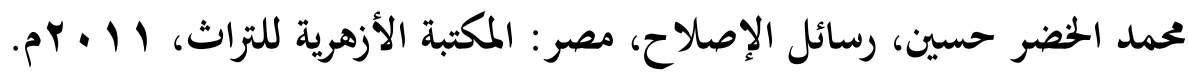
محمود شلتوت، محمد الخضر حسين، تحقيق: علي بن حسين الحلبي، السعودية:

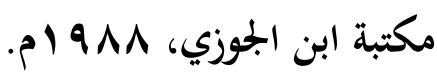

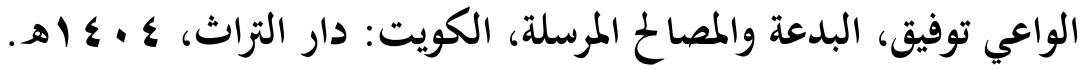

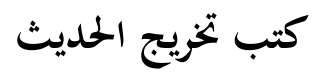


1491 